



\title{
MICROSCOPICAL OBSERVATIONS
}

MADE IN

\section{SOUTH CAROLINA. GEORGIA AND FLORIDA.}

\author{
J. W. B A I L E Y, \\ PROF. CHEMISTRY, ETC., U, S, MILITARY ACADEST, WEST POINT,
}

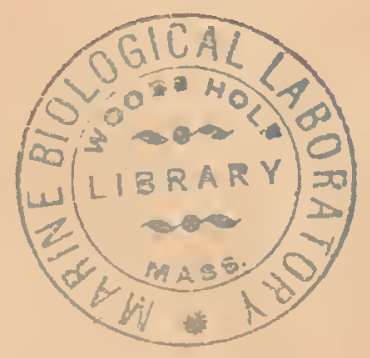

ACCEPTED FOR PUBLICATION

BY IHE SMITHSONIAN INSTITUTION, DECEMEER $1 \mathrm{ST}, \quad 1850$. 


\begin{abstract}
C O M I S I O N
TO WHICH THIS PAPER HAS BEEN REFERRED.
\end{abstract}

Prof. WM. B. Rogers,

Prof. Lewis R. GibBes.

JOSEPH HENRY,

Secretary of the Smithsonian Institution.

PIINTED BY EDWARD O. JENKINS,

114 Nassau street, New York. 


\title{
MICROSCOPICAL OBSERVATIONS
}

\author{
MADE IN

\section{SOUTH CAROLINA, GEORGIA, AND FLORIDA.}

THE observations here recorded were made during the winter and spring of the years 1849-50, while on a tour as an invalid through the Southern States. Although my researches were pursued under many disadvantages, and amount to scarcely more than a reconnoisance of the places visited, yet some facts of considerable interest were determined; and as the microscopic productions of these regions have never before been studied, some value must attach to even the most imperfect examinations. With this feeling, I offer the following notes, hoping that if they have no other interest, they may serve to point out to Southern naturalists, and the numerous intelligent invalids who hybernate in the South, how rich a field of amusement and instruction surrounds them even in midwinter.

Among the most interesting results obtained were-1st. The discovery of an extensive stratum of fossil Infusoria near Tampa Bay, (see page 19). 2d. The existence of vast quantities of infusorial remains in the rice fields and salt marsh formations of the South, (see pages 5, 11, 12, 13 and 20). 3d. 'The discovery of many new species of microscopic plants and animals, (see page 36). 4th. 'The demonstration of the cosmopolite character of many minute beings hitherto only known as European species, (see tables, pages '28, 31. and 33).

For the convenience of those microscopists who may hereafter visit any of the regions which I examined, I will state in detail the circumstances of time and place under which each observation was made, and give for each locality a list of the species, and then combine these into a general table, to illustrate the distribution of species. 
SULLIVAN'S ISLAND, S. C.

Dec. 11th, 1849.-On the logs and stones of the breakwater, in front of Moultrieville, I found the following forms:

DIATUMACFE.

Achnanthes longipes? Ag., forming very long bands, containing 50 to 100 frustules, mounted on a long footstalk. (See fig. 1, pl. 2.)

Amphora Lybica, Ehr.

Ceratoneis fasciola, whr.

Ceratoneis closterium, Ehr.
Coscinodiscus lineatus, Ehr. Grammatophora oceanica, Ehr. Gallionella sulcata, Ehr. Navicula sigma, Ehr. Liemophora radians, $\mathrm{Kg}$.

CIIARIESTON NECK.

Dec. 19th, 1849.--In company with Prof. Gibbes, of Charleston College, I collected the following forms in a fresh-water ditch near "the Lines," viz:

Bacillaria paradoxa, Ehr.

Synedra valens, Ehr.

Closterium acerosum, Schrank.

Cosmarium undulatum, Corda.

" cucumis, Corda,

" margaritiferum, 'lupp.

Euastrum ampullaceum, Ralfs.

Penium digitus, Elhr.
Scencdesmus obliquus, 'Turp.

Docidium nodulosum, Bréb.

Amblyophis viridis, Ehr.

A reella vulgaris, Ehr.

Euglena viridis, Ehr.

" pleuronectes, Elır.

Stentor polymorphus, Ehr.

\section{MUD OF CIIARLESTON IIARHOR.}

In mud collected from the logs of wharves, and from other situations in Charleston Harbor, the following species of Diatomacear were noticed.

Actiniscus sirius, Ehr.

Actinocyclus bioctonarius, Ehr.

Actinoptyehus senarius, Ehr.

Biddulphia pulchella, Gray.

Cocconeis scutellum, Ehr.

Coscinodiscus excentricus, Ehr.

Dietyocha fibula, Ehı:

Eupodiseus Rogersii, Ehr.

*Eupodiscus radiatus, B.

Gallionella sulcata, Ehhr.
Navicula sigma, Ehr.

Pinnularia interrupta, Kg.

" didyma, Ehr.

“ lyra, Ehr.

Rhaphoneis thombus, Ehr.

Stauroptera aspera, Ehr.

* Surirella circumsuta, B.

Terpsinoë musica, Ehr.

Triceratium favus, Ehr.

. alternans, B.

* Species marked with a star are believed to be new, and are described at page 36 . 


\section{CEDAR IIIII, ASHLEY RIVER.}

Dec. 15th, 1849.-At Mr. Dwight's plantation, (Cedar Hill,) I found growing abundantly on stems of grasses in the river, Bostrichia scorpioides and Delesseria Leprieurii Mont., two species of Alga which I have found in all our estuaries from the Hudson to Tampa Bay. In company with them in the Ashley River, I found-

Aclmanthes brevipes, $\Delta g$.

Meloseira nummuloides, Kig.

Bacillaria paradoxa, Ehr.

In fresh water ditches, at the same place, I found the following Alga, viz:

Vaucheria cespitosa, A $\mathrm{g}$.

Spirogyra reciuina, Kig.

witlı the following Diatomaceie, viz:

Bacillaria paradoxa, Elır.

Pinnularia viridis, Elır.

Diatoma Ehrenbergii, Kig.

Surirella splendisa. Ehr.

Himantidium areus, Ehr.

MIDDLETON PLACE, ASILEY RIVLR.

Dec. 16th, 1849.-In an artificial pond or reservoir at this locality, I found a great variety of interesting objects, among which were the following--

\section{DESMIDIE E.}

Ankistrodesmus falcatus, Corda.

Arthrodesmus conrergens, Ehr. incus, Bréb.

Cosmarium margariferum, Menegh.

Docidium verrucosum, $B$.

Euastrum elegans, Bréb.

Pediastrum ellipticum, Hass. heptactis, Menegh. Napoleonis, Menegh,

Scenedesinus quadricauda, Bréb. Sphaerozosma excavatum. Ralfs. serratum, B.
DESMIEIE.

Staurastrum graeile, Ralfs.

$$
\text { “. muticum, Bréb. }
$$

Xanthidium eristatum, Bréb.

$$
\text { IXIFUSORIA. }
$$

Areclla vulgaris, Ehr. dentata, Elur.

Lepadella ovalis, Ehr.

Monostyla lunaris, Ehr.

Peridinium cinctum, Elır.

Rotifer vulgaris, Schrank.

Squamella nblonga, Ehr.

\section{SAVANNAH, GA.}

December, 1849.--I had long entertained the belief that the earth of rice fields, from its frequent submergence, must contain a considerable quantity of infusorial remains; and on visiting Savannah, I gladly availed myself of the opportunity to determine the truth of this supposition. The amount of infusorial renuains which I detected far exceeded my expectations, but to my surprise I found that a large portion of the remains were of forms which only inlabit salt or brackish waters. Many of these forms are large enough to be seen by means of a pocket Coddington lens, and indeed it was thus that I first detected the infusorial cliaracter of the carths referred to. 'The large triangular 'Triceratium favus, Ehr., and the circular dises of Coscinodiscus subtilis, Elır., may thus be seen in considerable numbers on the surface of every fresh fracture of the earth thrown from the rice-field ditches. 
It is not merely the superficial layers which contain these remains, but earth thrown out from the depth of fifteen to twenty feet, as at the excavations for foundations and ditches at Fort Pulaski and Fort Johnson, abound in the same fossils, among which, besides Spongiolites and Phytolitharia, the following Diatomacex were noticed:

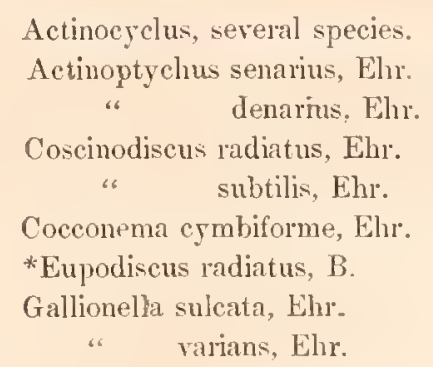

Pinnalaria placentula, Kg. " elliptica, Kig.

Rhaphoneis thombus, Ehr.

Surirella splendida, Ehr.

Triceratium favus, Ehr. “ alteruans, B.

Terpsinoë musica, Ehr.

Zygoceros rhombus, Ehr.

It will be noticed that all these forms are such as are now common in estuaries along the Atlantic coast.

In a fresh water ditch, about a mile below the city of Savannah, and communicating directly with the river, I found the following Diatomacer in a living state.

Bacillaria paradoxa, Ehr. Coscinodiseus subtilis, Ehr. Meloseira arenaria, Moore.
Pinnularia viridis, Ehr.

*Odontella Mobilensis, B., with spicules of sponge

In another fresh water ditch, in the same vicinity, I noticed among Draparnaldia glomerata, Ag., and Spirogyra quinina, Kg., the following forms, viz:

Closterium lumula, Ehr.

Coscinodiseus excentrieus, Ẻhr., dead.

Navicula hippocampus, Fhr.
Naunema, undeterminerl, with long slender frustules.

Srmedra vitrea, Ehr.

surirella splendida, Ehr.

\section{SWAMP ON THE ROAD TO BONAVENTURE, YEAR SAVANNAH.}

On the 24th of December, I collected Hydrocharis spongiosa, or "Coltsfoot," from a small swamp near the roalside, about a mile from Savannali; and on examining it with a microscope, I found that the small hairs which cover its aquatic roots give an admirable display of the phenomena of the circulation of the sap. These hairs are as transparent as glass, and in each one a turbid fluid may be seen in rapid motion, along the walls of the cells. Slowly revolving c t oblasts were also noticed in some of the hairs. Entangled among the roots of this plant I noticed specimens of Hydatina senta, Ehr., and frustules of Eunotia diodon, Elır. 
Near the same locality I found Botrydium argillaceum, Wall? and Vaucheria racemosa, Lyngb.

POND BY TIE NIDE OF THL RAIL-ROAD, NEAR SAYANNAII.

Dec. 27th, 1850.-The bottom of this pond was covered with beautiful, waving, plume-like masses of Myriophyllum, among the leaves of which the following species were found:-

Alst. E.

Bulbochrete setigera, $\mathrm{Ag}$.

Tolypothrix distorta, $\mathrm{K}$.

DESMIDIE.E.

Ankistrodesmus falcatus, Corda.

Aptogonum Baileyi, Ralfs.

Closterium setaceum, Elır.

Cosmarium Broomeii, 'Thwaites.

" cucumis, Corda.

" pyramidatum, Bréb.

Desmidium Swartzii, Ag.

Didymoprium Grevillii, Ralfs.

Docidium baculum, Bréb.

" verrucosum, B.

“ constrictum, B.

Euastrum crassum, Bréb.
DESMIDIE.E.

Euastrum didelta, Ralfs.

.. elegans, Bréb.

.. muricatum, B.

« rostratum, Ralfs.

Micrasterias Americana, Ralfs.

$$
\text { “ rotata, Ralfs. }
$$

Penium digitus, Bréb.

*Triploceras verticillatum, B.

* “ gracile, B.

Sphærozosma excavatum, Ralfs.

* " serratum, B.

Xanthidium cristatum, Ehr.

$$
\text { IXFusoria. }
$$

Arcella vulgaris, Ehr.

Peridinium cinctum, Ehr.

\section{DITCHES NEAR TIE CANAL OF SAVANNAH.}

On the road to the steam saw-mill, above Savannah and near the canal, the following species were seen in ditches, viz:

A LGA.

Chætophora pisiformis, Ag.

Nostoc, sp. undetermined.

Spirillum, sp. do. moving actively.

Spirogyra decimina, $\mathrm{Kg}$.

\section{DESUIDIE.}

Closterium acerosum, Schrank.

\section{DiatOMACEA.}

Bacillaria paradoxa, Ehr., abundant and active.

Gallionella aurichalcea, Elır.
Diatomacea.

Naunema, sp. undetermined, with long slender frustules. with lanceolate frustules.

Navicula amphirhynclus, Elır.

Synedra vitrea, $\mathrm{Kg}$.

$$
\text { INFUSORIA. }
$$

Arcella vulgaris, Ehr.

Englena viridis, Ehr.

Rotifer vulgaris, Schrank.

Synura uvella, Ehr. 
VICINITY OF GRAHA UYLLE, BEAUNORT DISTRIC'T, S. C.

Jamary, 1850.- In the ditches and "Backwater" of Dr. Bolen's rice field, near Grahamville, S. C., I detected the following species on the Ist of January, 1850.

DesMliditi.

Ankistrodesnus falcatus, Cordit.

Aptogonum Baileyi, Ralfs.

Arthrodesmus convergens, Ehr.

Closterium acerosum, Schrank. setaceun, Ehr.

Cosmarium ovale, Ralts.

Desmidium Swartzii, Ay.

Didymocladon furcigerus, Ralfs.

Didymoprium Borreri, Ralfs.

Docidium clavatun, Bléb.

s. minutum, Ralfs.

" nodulosum, Bréb.

Hyalotheca dissiliens, Bréb.

Micrasterias furcata, Ag. " Baileyi, Ralfs.
UESMIDIEAE.

Micrasterias fimbriata, Ralfs.

Americana, Ralfs.

* Sphrerozusma scruatum, B.

Staurastrum margaritaceum, Ehr.

INFTSUlid.

ilctinuphrys viridis, Elır.

Arcella rulgaris, Ehr.

Megalotrocha albothavicans, Ehr.

Ophrydium versatile, Ehr.

*Peridinium Caroliniantum, B.

Rotifer vulgaris, Schr.

Stentor polymorphus, Ehr.

Vorticella chlorostigma, Ehr.

Hydra viridis.

'This locality is chiefly remarkable for the great abundance of the curious and. novel form Peridinium Carolinianum. See p. 41.

GRAIIAMILLE, s c.-contimed.

In a small ditch by the side of the road leading from Grahamville to Savannah, and about a mile from Grahamville, the following forms were seen, viz:

DESMIDI". A.

Cosmarium margaritiferum, Menegh., abundant.

Euastıun crassum, Bréb.

" insigne, IIass.

Micrasterias crenata, Bréb.

“ denticulata, Bréb., abundant.

\section{DESMIDIE:E.}

Tetmemorus Brebissonii, Ralfs., abundant.

" granulatus, Ralfs.

DIATOMACE.E.

Eunotia tetraodon. Ehr.

GLAIIAMVILLE, S. C.-contimed.

In pools near the dam of a "Backwater," on the road to Savanualı, about two and a half miles from Grahamville, great numbers of the following species were found, viz:

\section{DESMIDIE.E.}

Closterium lumula, Ehr.

Desmidium Swartzii, Ag.

Didymoprium Borteri, Ralfs.

Docidium Ehrenbergii, Ralfs.

" mimutum, Ralfs.

“ nodulosum, Bréb. .

Euastrum ansatum. Ehr.

“ affine, Ralfs.

" didelta, Ralfs.

Micrasterias crenata, Breb.
DesMidies.

Micrasterias denticulata, Bréb.

Penium closteroides, Ralfs.

(in inmense numbers.)

Spirotenia condensata. Bréb.

$$
\text { INFUSORIA. }
$$

Arcella vulgaris, Ehr.

" hyalina, Ehr.

Difflugia protexformis.

* “ spiralis. B. 
GRAHAUVILLE, s. C.-contimued.

In a ditch by the roadside, near Gopher Hill, I found-

Micıasterias pinnatifida, Ralfs.

Xanthidium armatum, Ralfs.
Pinnularia amphigompha, Ehr.

" iridis, Elyr.

GRAIIUVILLE, s. C.-contimued.

Near the village, by the side of the road to "Hap Hazard," I found among the roots of Utricularia verticillata, the following species, viz:

\section{DESMIDIEA.}

Aptogonum desmidium, Ehr.

Closterium acerosum, Schr.

Desmidium Swartzii, Ag.

Didymoprium Grevillii, Ralfs.

Euastrum aftine, Ralfs.

Penium interruptum, Bréb.

Spirotænia condensata, Bréb.

Janthidium cristatum, Bréb.

" fasciculatum, Ehrr.
Diatomace.e.

Himantidium bidens, Ehr.

Diatoma stellata, B.

INRUSURIA.

Amceba princeps, Ehr.

Arcella vulgaris, Ehr.

" hyalina, Ehr.

Dinobryon sertularia, Elrr.

Hydatina senta, Ehr.

*Peridinium earolinianum, $\mathrm{B}$.

Pterodina patina, Ehr.

GRAIIAUILLE, S. C.-contimucd.

A ditch by an old saw-mill near the village furnished these species, viz:

\section{DESMIDIEA.}

Euastrum ansatum, Elrr., abundant.

Hyalotheca dissiliens, Bréb.

Micrasterias rotata, Ralfs.

Penium closteroides, Ralfs.

“ interruptum, Bréb.

Spirotænia condensata, Bréb.
DIATOMACEÁ.

Naunema, undetermined.

Surirella splendida, Ehr.

\section{ALGA.}

'Tetraspora lubrica, $\mathrm{Ag}$.

Vaucheria cespitosa, Ag., with a parasitic Rotifer in its branches.

\section{GRAHAMVILLE, s. c.-contimucel.}

The mill-pond at "Hap Hazard" furnished the following species, vi\%:

DESMIDIEA.

Closterium acerosum, Schr. “ lunula, Ehr.

Didymoprium Borreri, Ralfs.

Docidium nodulosum, Bréb.

Euastrum verrucosum, B.

Micrasterias incisa, $\mathbf{K g}$.
Micrasterias denticulata, Bréb.

Penium digitus, Bréb.

Scenedesmus obliquus, $\mathrm{Kg}$.

*Sphrorozosma serratum, B.

Spirotrenia condensata, Bréb.

Staurastrum margaritaceum, Ehr. 
Amœba princeps, Ehr.

Arcella vulgaris, Ehs.

" dentata, Ehr.

Epistylis anastatica, Ehr.
INFUSORIA.

Hydatina senta, Ehr.

Rotifer vulgaris, Schr.

Scaridium longicaudum, Ehr.

Stentor polymorpha, Ehr.

\section{HAZARD'S BACK CREEK, NEAR GRAHAMVILLE, S. C.}

In the floating scum of this salt water creek, at Mr. Bolen's Landing, the following Diatomacea were detected:-

Amphiprora alata, Ehr.

Amphora libyca, Ehr.

Bacillaria paradoxa, Ehr.
Coscinodiscus subtilis, Elur.

Naricula Baltica, Elır.

Pinmularia interrupta, Ehr.

The following Alga were also found at the same place, viz:

Dclesseria Leprieurii, Mont.

Ectocarpus littoralis, Lyngb.

BRYAN COUNTY, GA.

Jamuary and February, 1850.-In ditches by the side of the Ogeechee Causeway, on the road from Savannah to Darien, I noticed the following species among the roots of Utricularia verticillata, which grows here in great profusion.

DesMidie.s.

Ankistrodesmus falcatus, Cordal.

Arthrodesmus convergens, Ehr.

Closterium accrosum, Schr.

$$
\begin{array}{ll}
\text { “ Ehrenbergii, Nenegh. } \\
\text { “ Leiblenii, Kg. } \\
\text { " setaceum, Ehr. }
\end{array}
$$

Didy moprium Borreri, Ralfs.

Docidium Ehrenbergii, Ralfs.

$$
\text { " nodulosum, Bréb. }
$$

Euastrum rostratum, Ralfs.

Micrasterias americana, Ralfs.

" denticulata, Bréb.

* incisa, $\mathrm{Kg}$.

"rotati, Ralfs.
DIATOMACEA.

Himantidium arcus, Elır.

'labellinia tloceulosa, Ehr.

\section{INFusoria.}

Arcella dentata, Ehr.

" vulgaris, Ehr.

Euglena pleuronectes, Elur.

Euplotes charon, Ehr.

Rotifer vulgaris, Schr.

" macrurus, Ehr".

Stentor polymorpha, Ehr.

Synura urella, Elur.

$$
\text { A LGi. }
$$

*Aporea ambigua, B. (Pl. 3, fig. 3.)

Bulbochæte setigera, $\mathrm{Ag}$.

Coleochæte scutata, Bréb.

At the same locality, Hydrocharis spongiosa, Riccia fluitans, and a species of Azolla, occur abundantly. 
BRYAN CO., GA.-continued.

RICE FIELD MUDS.

The mud from the rice fields on the Ogeechee was collected at the embankments by the side of the canals and ditches on the following estates, viz:

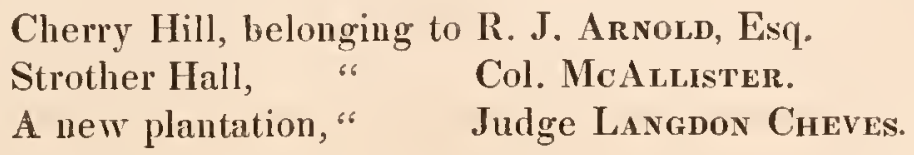

These muds all agreed in character with those examined near Savannah, and furnished the following species, viz:

Actinoptychus denarius, Elır. senarius, Ehr.

Cosemodiseus excentricus, Ehr.

$$
\text { of subtilis, Ehr. }
$$

Dictyocha fibula, Ehr.

Gallionella sulcata, Ehr.

Pinnularia intermpta, Kg.

" viridis, Ehr.

Rhaphoneis rhombus, Ehr.

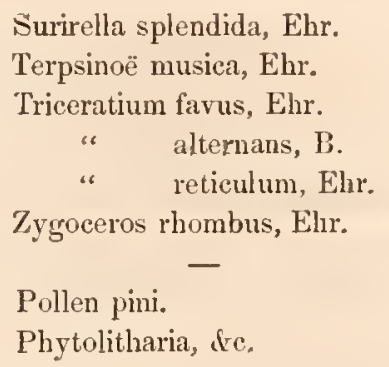

BRYAN Co., GA.-contimued.

In a ditch of an old rice field, and at some distance from the river, the following species were found among the leaves of Utricularia verticillata, viz:

Bacillaria paradoxa, Ehr.

Gallionella aurichalcea, Elir.

Himantidium areus, Ehr.

Synedra spectabilis, Ely:

“ vitrea, Ehr.
Closterium acerosum, Schr.

Arcella dentata, Ehr.

Vaginicola crystallina, Ehr.

DITCH NEAR THE CHURCII IN THE VICINITY OF WHTE HALI,

This furnished the following:

Ankistrodesmus faleatus, Corda.

Aptogonum desmidium, Ehr.

Arthrodesmus convergens, Ehr.

$$
\text { " incus, Bréb. }
$$

Didymoprium Borreri, Ralfs.

Docidium verrucosum, $\mathbf{B}$.

Euastrum affine, Ralfs.
DESMIDIE.E.

Micrasterias crenata, Bréb.

Pediastrum heptactis, Menegh.

Penium digitus, Bréb.

Scenedesmus obliquus, $\mathrm{Kg}$.

Staurastrum dejectum, Bréb.

" gracile, Ralfs.

Santhidium aculeatum, Ehr. 
Diatonace.e.

Pinnularia amphigompha, Ehr.

Diatoma stellaris, B.
INFUSORIA.

Dinobryon sertularia, Ehr. Euglena longicauda, Ehr. Peridinium cinctum, Ehr. Rotifer vulgaris, Schr. Stentor polymorpha, Ehr.

GLYNN COUNTY, GA.

HOPETON, ON THE ALTAMAHA, RESIDENCE OF J. HAMILTON COUPER, ESQ.

About the time when I arrived at Mr. Couper's hospitable mansion, there had been several severe frosts, and some days of cold rains. Under these circumstances, the opportunities to collect the microscopic forms were much less fivorable than at the preceding localities. 'The rice-field muds at this locality proved to be quite rich in remains of diatomaceous shells, agreeing with those noticed on the Savannah and Ogeechee, and furnishing abundance of the following forms, vi\%:

Antincreyelus, several species.

Actinoptychus denarius, Ehr. senarius, Ehr.

*Campylodiseus argus, B.

Eupodiscus Rogersii, Ehr.

* “ radiatus, $B$.

Gallionella sulcata, Elhr.

Pinmularia amphṛoxys, Ehr.
Pinnularia interrupta, Kg.

" viridis, Ehr.

Rhaphoneis rhombus, Ehr.

Terpsinoë musica, Ehr.

Triceratium farus, Ehr.

" reticulum, Ehr.

Zygoceros rhombus, Ehr.

In a rice-field ditch, remote from the river, I found the following species in a living state, viz:

DESMIDIE.E.

Closterium lanceolatum, $\mathbf{K} g$.

Desmidiun Swartzii, Ag.

Micrasterias crenata, Bréb.

Scenedesmus obliquus, Kig.

\section{DIATOMACE.E.}

Coconema cymbiforme, Ehr.

Eunotia gibbi, Ehr.

" librile, Ehr.

" amphyoxys, Ehl.

Fragillaria pectinalis, Ehr., in large masses.

Gallionella aurichalcea, Ehr.

Gomphonema constrictum, Ehr.

Navicula hippocampus, Ehr.

Naunema. undet. frustules slender.
DiatonaCE.E.

Surirella splendida, Ehr.

Synedra vitrea, IIg.

INEUSORIA.

Gonium pectorale, Ehr.

Hydatina senta, Ehr.

Lacinularia socialis, Ehr.

Synura uvella, Ehr.

Vaginicola crystallina, Ehr.

$$
\text { ALGE, de. }
$$

* A porea ambigua, B.

Coleochrete scutata, Bréb.

Mougeotia genuflexa, Ag. 
HOPETON.-contimued.

In a ditch leading from a small artesian well in the rice fields at Hopeton, the following forms were noticed, viz:

Closterium lunula, Ehr.

“ lanceolatum, $\mathrm{K}$ g.

Eunotia gibba, Ehr.

Surirella splendida, Ehr.

\author{
Synecha vitrea, Kg. \\ Areclla dentata, Ehr. \\ Euglena viridis, Ehr. \\ Rotifer vulgaris, Schr.
}

In a ditch behind the Negro Hospital at Hopeton, I found the following, viz:

\author{
Closterium Diance, Ehr. \\ " moniliferum, Ehr. \\ Docidium clavatum, $\mathrm{Kg}$. \\ llimantidium areus, Ehr. \\ Synedra vitrea, Kg.
}

Dinobryon vulgaris, Ehr.

Peridinium cinctum, Elır.

Rotifer rulgaris, Sclrr.

and several species of Cyclops, Daphnin and Gammarus.

GLYNN co., Ga.-contimed.

ST. SIMON'S ISLAND.

In the salt marsh mud from the "Cut-off" at the north end of St. Simon's Island, the following species were found, either alive or evidently in a very recent condition, viz:

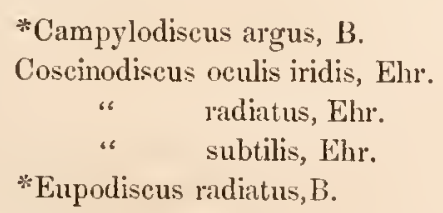

\author{
Gallionella sulcata, Ehr. \\ Rhaphoneis rhombus, Ehr. \\ Terpsinoë musica, Ehr. \\ Triceratium favus, Ehr. \\ Zygoceros rhombus, Ehr.
}

The same forms were noticed in mud from the "Inland Passage" from Darien to Jacksonville, Fa. The resemblance of these marsh muds to those thrown out in digging the canals of the rice fields, and the identity of the forms contained in them, serve to show that the rice fields were once salt marshes, and have been cut off from the influence of the ocean either by elevations of the coast, or changes in the conrse of the rivers. It should be borne in mind, however, that marine forms occur in estuaries far above where the surface water is brackish. 


\section{F L O R I D A.}

PIIATKA.

Feb. 20th, 1850.-In sphagnous swamps, near the village of Pilatka, Florida, I found the species named below.

DESMIDIE.A.

Closterium acerosum, Schr. Dianæ, Ehr.

*Cosmarium depressa, B.

Didymoprium Borreri, Ralfs.

Didymoeladon furcigerus, Ralfs.

Docidium minutum, Ralfs.

Euastrum elegans, Bréb.

$$
\text { “ sublobatum, Bréb. }
$$

Mierasterias truneata, Bréb.

Penium digitus, Bréb.

Staurastrum graeile, Ralfs.

" tricorne, Bréb.

" polymorphum, Bléb.

Janthidium armatum, Ehr.

" faseieulatum, Ehls.
Dratomaceie.

Himantidium diodon, Ehr.

Pinnularia viridis, Ehr.

INFUSORIA.

Aetinophrys viridis, Flır.

Amceba princeps, Ehr.

Arcella dentata, Elır.

“ vulgaris, Ehr.

Metopidia lepadella, Ehr.

Nonostyla lumaris, Elur.

Noteus quadricomis, Ehr.

Pterodina patina, Ehr.

Rotifer vulgaris, Schr.

Stylonychia mytilus, Ehr.

Cothurnia imberbis, Ehr.

PILATKA.-continued.

The following species were found in a living state, attached to a $\log$ in the St. John's River, at Pilatka, viz:

Bacillaria paradoxa, Ehl.

Odontella polymorpha, Ky.

*Campylodiscus argus, $B$.

PILATKA,-contimed.

In a ditch by the roadside, three miles from Pilatka, I found these species, viz :

DESMIIE.E.

Didymoprium Bonreri, Ralfs. (in conjugation.)

" Grevillii, Ralfs.

Euastrum ampullaeeum, Ralfs.

Hyalotheea dissiliens, Bréb.

Tetmemorus Brebissonii, Ralfs.
Diatomace.

Eunotia tetraodon, Ehr.

INFUSORIA.

Colurus tricuspidatus, Ehr.

Dinobryon sertularia, Ehr.

Pterodina patina, Ehr.

Stentor polymorphus, Ehr. 
PONOS NEAR PILATKA.

In the "First Pond," about five miles west of Pilatka, the following species were collected, viz:

DESMIDIE.E.

Ankistrodesmus falcatus, Corda.

Cosmarium amœenum, Bréb.

pyramidatum, Bréb.

Didymoprium Borreri, Ralfs.

Docidium Ehrenbergii, Ralfs.

Euastrum clegans, Bléb.

Micrasterias truncata, Bréb.

Spirotrenia condensata, Bréb.

Sphærozosma excavatum, Ralfs.

* " scrratum, B.

Staurastrum dejectum, Bréb.

'Tetmemorus Blebissonii, Ralfs.
DESMIDIEA:

Xanthidium fasciculatum.

INFLSORM.

Arcella angulata, Ehr.

Euglena longicauda, Ehr.

Megalotrocha alboflavicans, Ehr.

Monostyla lunaris, Elrr.

*Pcridinium carolinianum, B.

$$
\text { Alti.e. }
$$

*A porea ambigua, $B$.

Bulbochrete setigera, Ag.

In the "Second Pond," near the above locality, were found-

*Cosmarium depressum, B.

*Didymocladon cerberus, $\mathrm{B}$.

* Micrasterias arcuata, B.

* " expansa, B.
Micrasterias furcata, Ehr.

" radiosa, Ehr.

Penium digitus, Ralfs.

Xanthidium faseiculatum, Ehr.

PILATKA.-continued.

In a deep ravine south of Pilatka, I found large brown masses of Diatoma Ehrenbergii, $\mathrm{Kg}$., attached to twigs, etc., in a small stream.

\section{SIIELI, BANKS OF PIIAT'KA.}

While at Pilatka, I carefully examined the immense deposit of fluviatile shells upon which the town is built, and which is chiefly made up of Paludina vivipara, Ampullaria depressa, several small Helices, Melanix, etc., with valves of an undetermined Unio. I could detect no trace of microscopical organisms in any of the earthy matter accompanying them. 


$$
\text { PILES" "NEW PLACE," FA. }
$$

At "Piles'," about forty miles west of Pilatka, on the road to Tampa, I examined the rock recently excavated in forming a well. It proved to be the White Orbitulite lintestone, containing large masses of flint. Both the limestone and flint abound in microscopical Polythalamia, which may be detected in the llint by mounting thin fragments in Canada balsam. Rock of similar character was seen at numerous places between Pilatka and Tampa, and it even forms extensive ridges, of the height of three or four hundred feet, giving an appearance to the interior of Florida very different from the flat monotonous aspect which it is generally supposed to present.

OCALA, FA.

Feb. 26th, 1850.-In a "Lime-sink" near Ocala, on the road to 'Tampa, I found the following forms among the roots of Lemna minor, which covered the surface of the water, viz:

Docidium nodulosum, Bréb.

Cosmarium Thwaitesii, Ralfs.

margaritaceum, Menegh.

Arcella vulgaris, Ehr.

Euglena pleuronectes, Ehr.

Rotifer vulgaris, Sclir.
Salpina mueronata, Ehr.

*A porea ambigua, B.

Coleuchrete scutata, Bréb.

'Iyndaridea cruciata, Harv.

spirogyra quinina, Kg.

\section{DADE'S BATTIE GROUND, FA.}

At the pond near Dade's Battle Ground, I found the following forms, viz:

DESMIDIEA.

Arthrodesmus convergens, Ehr.

" - incus, Bréb.

*Cosmarium depressum, B.

" commatum, Bréb.

" margaritiferum, Menegh.

" ornatum, Ralfs.

Docidium mimutum, Ralfs.

Euastrum binale, Ralfs.

" elegans, Bréb.

Micrasterias crenata, Bréb.

$$
\begin{array}{ll}
\text { “ } & \text { incisa, } \mathrm{Kg} . \\
\text { “ } & \text { pinnatifida, } \mathrm{Kg} . \\
& \text { radiosa, } \mathrm{Ag} .
\end{array}
$$

Desmidie.

*Micrasterias ringens, $\mathrm{B}$.

Pediastrum Boryanum, Menegh. heptactis, Menegh.

*Sphærozosma serratum, B.

Xanthidium cristatum, Bréb.

$$
\text { Infusoria. }
$$

Areella dentata, Ehr.

* Difflugia spiralis, B.

Gonium glaueum, Ehr.

Rotifer rulgaris, Schr.

Salpina mucronata, Ehr. 


\section{DITCH BY ROADSIDE, TIIRTY MILES EAST OF TAMPA.}

At this locality I collected the following :

Cosmarium pyramidatum, Bréb.

Docidium minutum, Ralfs.

Euastrum sublobatum, Bréb.

Micrasterias pinnatifida, Kig. truncata, Bréb.
Penium digitus, Bréb.

Pterodina patina, Ehr.

Rotifer vulgaris, Schr.

Stentor polymorpha, Ehr.

\section{"WARM SPRING" ON THE ROAD TO TAMPA.}

This spring furnished the following species, viz:

Closterium Ehrenbergii, Menegh.

- “ turgidum, Ehr.

Docidium nodulosum, Bréb.

Cocconema cymbiforme, Ehr.
Eunotia gibba, Ehr.

.. librile, Ehr.

Gallionella aurichalcea, Ehr.

Himantidium areus, Ehr.

The surface of the spring was covered with a green mucous mass, composed of Nostoc-like filaments, mingled with Mougeotia genuflexa, Ag., and Spirogyra decimina, $\mathrm{Kg}$.

\section{LITTLE HILLSBOROUGH RIVER, ON THE ROAD FROM PILATKA TO TAMPA.}

This river furnished the following, viz:

DesMidies.

Closterium Dianæ, Ehr. .

“ Ehrenbergii, Nenegh.
DiatoMACE.E, \&C. Cocconeis pediculus, Ehr. Cocconema cymbiforme, Ehr. *Peridinium carolinianum, B. Pinnularia viridis, Ehr. Synedra vitrea, Kig.

WITILACOOCIEE RIVER, ON THE ROAD TO TAMPA.

March 1st, 1850.--In this river I found, among the roots of Pistia stratiotes, the following species, viz:

DESMIDIE.E.

Closterium Dianæ, Ehr.

“ Ehrenbergii, Nenegh.

" setaceum, Ehr.

Micrasterias americana, Ralfs.

Diatomace, \&C.

* Amphiprora ornata, B. Pl. 2, figs. 15 and 23.
Cocconeis pediculus, Elır.

Cocconema cymbiforme, Ehr.

Eunotia gibba, Ehr.

“ librile, Ehr.

Fragillaria pectinalis, Ehr.

Himantidium arcus, Ehr.

Surirella splendida, Ehr.

Synedra vitrea, Kg. 
BIG IILLSBOROUGI RIVER, ON TIE ROAD FROM PILATKA TO TAMPA.

In this river I noticed the following species in a living state:

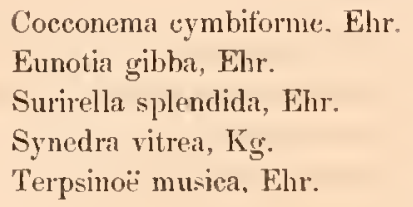

Arcella dentata, Ehr.

" vulgaris, Ehr.

Batrachospermum moniliforme, Roth. Spirogyra decimina, Kig.

It was at this locality that I first saw living chains of that exquisite form, the Terpsinoë nusica, Ehr. The frustules contained yellowish endochrome and granules, irregularly scattered.

\section{VICINITY OF TAHPA, (FORT' BROOKE), FA.}

The mud of a salt-marsh, lalf a mile east of Fort Brooke, furnished the following Diatomacex, viz:

Amphiprora constricta, Ehr.

Coscinodiscus subtilis, Ehr.

*Eupodiscus radiatus, B.

Gallionella sulcata, Ehr.
Navicula baltica, Ehr.

Stauroptera aspera, Ehr.

Triceratium favus, Ehr.

. reticuhum, Ehr.

TAMPA.-contimued.

On the shores of Hillsborough River, near the Hotel at 'Tampa, I noticed that the sand below high-water nark was of the peculiar yellowish or ferruginous tint which often indicates the presence of living Diatomacex. Microscopical observations proved the presence of large numbers of a species of Amphiprora, (see figs. 2, 3, 4, Pl. 2,) whose living frustules showed four parallel yellowish bands, and which I shall refer to as Amphiprora fasciata, B. A small sigmoid Navicula, probably N. sigma, Ehr., accompanied the Amphiprora.

About a mile and a half above the Hotel, I collected some salt-marsh grasses, attached to which were great quantities of Delesseria Leprieurii, Mont., and Bostrichia scorpioides? and among these Alga I detected the following:

Diatomachas.

Achnanthes brevipes, Ag.

Bacillaria paradoxa, Ehr.

Cerataulus turgidus, Ehr.

Meloseira salina, Kig.

Stauroptera aspera, Ehr.

Triceratium favus, Elır.
INFUSURIA.

Carehesium polypinum, Ehr.

Cothurnia maritima, Ehr.

havniensis, Ehr:

Higures of these species of Cothurnia are given on Pl. 3, figs. $11 \& 12$. 
TAMPA.-continued.

On the beach in front of the flagstaff at Fort Brooke, I collected the follorving :

\begin{tabular}{|c|c|}
\hline $\begin{array}{l}\text { Alg.E. } \\
\text { Sargassum vulgare, } \mathrm{Ag} \text {. } \\
\text { Spyridia filamentosa, Harv. } \\
\text { Ceramium clavulatum, } \mathrm{Ag} \text {. }\end{array}$ & $\begin{array}{l}\text { Diatomaces. } \\
\text { *Achnanthes? arenicola, B, see page } 38 \text {. } \\
\text { Bacillaria paradoxa, Ehr. } \\
\text { Grammatophora stricta, Ehr. } \\
\text { Gallionella sulcata, Ehr. } \\
\text { Rhabdonema adriaticum, Kg. }\end{array}$ \\
\hline
\end{tabular}

On the west side of the bay, the following Algie were found on the beach at low tide, viz:

Bangia fusco-purpurca, Lyngh.
Calothrix confervicola, $A g$.
Ceramium clavulatum, Ag.
Gracilaria multipartita, J. Ay.
Polysiphonia Olney? Har.

\section{INFUSORIAI, NTKATUM NEAR TAMPA.}

Between the ferry at Tampa and the well known locality of silicified corals at Ballast Point, on Hillsborough Bay, and directly on the shore of the bay, I detected a highly interesting stratum of fossil marine Diatomacese or Infusoria. It is exposed for at least a quarter of a mile along the shore, and from five to ten feet of its thickness may be seen. In its external characters, (whiteness, lightness, fissility, \&c.,) it has some resemblance to the infusorial strata of Virginia, but is much more indurated, so that, although it is easy to show that it is made up of the remains of Diatomace $x$, spicules of sponges, \&c., it is yet difficult to isolate and determine the individual species. The following forms, how ever, were distinctly recognized, viz:

Actinoptychus senarius, Ehr.

Coscinodisei, undetermined fragments.

Denticclla ? tridentata, Ehr:=Zygoceros Tuomeyi, B.

with numerous sponge spicules.

This infusorial earth, like that at Petersburg, Va., changes in a singular manner, to a salmon color, when exposed to the vapor of Turpentine or Canada Balsam. The geological position is probably in the upper part of the Eocene Tertiary, for a bed of shells, which apparently belong to that epoch, lies a short distance to the east of the infusorial bed.

This discovery of a marine infusorial stratum, similar to those of Virginia and Maryland, but at so great a distance from them, is, I think, of much interest, and gives reason to hope for the detection of similar deposits at many intermediate points.

Some interesting remarks on the geology of the localities in the vicinity of 'Tampa and Ballast Point, by J. H. Allen, may be found in Silliman's Journal, New Series, Vol. I., p. 38, and others by 'T. A. Conrad, in the same series, Vol. II., pp. 36, 399. 
ST. AUGUSTINE, FA.

March 16th, 1850.-The mud of the St. Sebastian River, collected at the bridge west of St. Augustine, proved to be very rich in siliceous shells of recent and living Diatomacea, among which the following were noticed, viz:

Actinoptychus senarius, Ehr:

Actinocyclus, sẹreral species.

Biddulphia pulchella, Gray.

Coscinodiscus excentricus, Ehr:

" lineatus, Ehr.

" oculus-iridis, Elır.

" subtilis, Ehr.

Dityocha fibula, Ehr

*Eupodiscus radiatus, B.

" Rogersii, Ehr.

Gallionella sulcata, Ehr.

Meloseira salina, Kig. $\uparrow$ Navieula elongata.

" baltica, Ehr.

*Pinnularia Couperi, B.

“ lyra, Ehr.

*Pyxidicula compressa, B.

Rhaplıoneis rhombus, Ehr.

Stauroptera aspera, Ehr.

* Surirella circumsuta, B.

" splendida, Ehr.

Triceratium farus, Ehr.

" hexagonalis, $\mathrm{B}$.

Zygoceros rhombus, Ehr.

'The following Alg:e were found at the same place, viz:

Bostrichia scorpioides? Mont.

Delesseria hy poglossum, Lamour.

Leprieuii, Mont.
Porphyra rulgaris, Ag.

Ulva latissima, $L$.

\section{ST. AUGUSTINE.-contimued.}

In the mud at the foot of the sea wall, near the old Spanish Fort St. Marco, I noticed the following Diatomacer, viz:

Ceratoneis closterium, Ehr. very active.

Coscinodiscus lineatus, Elır.

“ radiatıs, Ehr.

" subtilis, Ehr.
Grammatuphora marina, Ehr.

Navicula baltica, Ehr.

“ signa, Ehr.

The following Algæ were also noticed at the same locality, viz:

Bostrichia scorpioides? Mont.

Callithamnion, undetermined.

Ectocarpus siliculosus, Lyngb.

Gelidiun corncum, Lamour.
Gracilaria multipartita, Clem.

Rhabdonia Baileyi, Harv.

Spyridia filamentosa, Wulf.

$†$ Specimens which I received from London, agreeing well with our own, were marked $\mathbf{Y}$. elongata, but by whom they were so named 1 do not know. I had been in the habit of calling it $N$. diagonolis, but had not published any notice of it. Its delicate diagonal, transverse, and longitudinal rows of dots make it an interesting nicroscopic object. 
In a grayish slime covering the creek west of St. Augustine I found

Amphiprora alata, Ehr. See figs. 8, 9, 10, Pl. 2

Amphora libyea, Ehr.
Pinnularia interrupta, Ehr.

Rluaphoneis rhombus, Ehr.

In a fresh-water pond, on St. Anastasia Island, near St. Augustine, I found on the 26th March, 1850, the following, viz:

A LG.E.

* A porea ambigua, B.

Cliatophora pisiformis, $\mathrm{A} g$.

Coleochrete scutata, Bléb.

In fruit, abundant on petiules of Sagittaria.

$$
\begin{aligned}
& \text { Arcella vulgaris, Ehr. } \\
& \text { *Pterodina magna, B. } \\
& \text { Rotifer vulgaris, Schr. } \\
& \text { Stentor polymorphus, Ehr. }
\end{aligned}
$$

Diatomace.e.

Himantidium arcus, Ehr.

Cocconeis pediculus, Fhr.

Piunularia viridis, Ehr.

S'T. ANASTASIA ISLAND.-contimued.

On the "Coquina" Rocks, near the light-house, on Anastasia Island, I found the following forms, viz:

\author{
ALG.※. \\ Ceramium rubrum, $\mathrm{Ag}$. \\ Gelidium corneum, Huds. \\ Laurencid dasy phylla, Woodw. \\ Rhabdonia Baileyi, Harv.
}

\section{DIATOHACEA.}

Achnanthes minutissima, $\mathrm{Kg}$. Rhipidophora crystallina, $\mathbf{K g}$. Schizonema quadripunctata, $\Lambda \mathrm{g}$.

Acineta Lyngbyi ? Ehı. See fig. 16, Pl. 3.

On the sands of the above locality I noticed yellowish spots, which owed their color to great numbers of Amphiprora quadrifasciata, B., and a species of Amphora, apparently new, which moved very rapidly. I have named it Amphora amphioxys, B. See page 38 .

\section{ST. AUGUSTINE.-continued.}

In fresh-water ditches in the pine barrens near. St. Augustine, I observed these forms, viz:

Closterium acerosurn, Schr.

“ Dianæe, Ehr.

، turgidum, Elir.

Euastrum oblongum, Ralfs.

Staurastrum dilatatum, Ehr.

Eunotia diodon, Ehr.
Brachionus urceolaris. See fig. 17.

Bulbochæe te setigera, $\mathrm{Ag}$.

Mougcotia genuflera, $\mathbf{\Lambda g}$.

Tyndaridea cruciata, Harv., in fruit. 
VOLUSIA, ON THE ST. JOHN'S RIVER, FA.

On the roots of the "Water Lettuce," Pistia stratiotes, L., I I collected at Volusia, on the 9th of April, 1850, the following species, viz:

\section{Diatomace.}

Achnanthes, undetermined. See fig. 11, Pl. 2.

Amphora libyca, Elr. Fis, 12, Pl. 12.

Bacillaria paradoxa, Ehr. Abundant, and rery active.

Cocconeis pediculus, Ehr.

Cocconema cymbiforme, Ehr.

Eunotia gibba, Ehr:

“ nodosa, Ehr.

" lilrile, Eihr.

Gallionella aurichalcea, Ehr.

" rarims, Ehr.

Himantidium arcns, Ehr.
Naricula elongata, Harrison?

Odontella polymorpha, Kig.

Synedia vitrea, $\mathrm{kig}$.

Terpsinoë musiea, Ehr. Living, and forming zigzag chains.

$$
\text { INFCSORIA. }
$$

Amceba princeps, Ehr.

Arcella vulgaris, Ehr.

Rotifel vulgaris, Schr.

DESMIDIE.T.

Staurastrum enorme, Ralfs.

ENTERIRISE, FA.

Latitude between 28' and 29. $\mathrm{N}$.

Aprit 10th to 23d, 1850.-On Lake Monroe, 200 miles from the moutl of the St. John's River. This was the most southern point which I visited, and there is no place which I have ever seen which aflorded so many delights to the microscopist. The sub-tropical climate produces in the numerous lakes and creeks countless myriads of the most interesting Infusoria and Desmidiex, which may be collected within a few hundred yards of the boarding-house. The numerous sulphur springs, surrounded by beautiful palmetto groves; the parasitic 'Tillandsias of several species; the epidendri and parasitic ferns; the lake with its hundreds of alligators, and its strange mixture of marine and fresh-water forms ; and lastly, the wonderful shell banks on which Enterprise is built, are all calculated to interest even the most indifferent. I would be glad if every invalid who visits this place could pass as many pleasant hours there as it was my privilege to enjoy.

In Lake Monroe I collected, from anong the roots of Pistia stratiotes, the following species, vi\%:

\section{DESMUDIE.}

Closterium Jenneri, Ralfs.

Euastrum ampullaceum, Ralfs.

Pediastrum boryanum, Menegh.

$$
\text { ALG.T. }
$$

Coleochæete scutata, Bréb.

Spyrogyra quinina, Ǩg.
DIATOMACE E.

Amphiprora constricta, Ehr. Pl. 2, figs. 5, 6, 7. pulchra, B. Pl. 2, figs. 16 and 18 .

Bacillaria paradoxa, Ehr.

Campylodiscus clypeus, Ehr.

* " argus, B. Pl. 2, figs. 24, 25.

Cocconeis pediculus, Ehr.

Cocconema cymbiforme, Ehr.

+ 'This gigantic representation of the Lemna of the northem waters grows in vast profusion in the Withlacoochee and St. John's Rivers. Like the Lemna, it contains spiral vessels in its ronts, and abounds with liformes. which atively discharge their laphicles in water. See Pl 3. fig. I. 
ENTERPRISE, HA.-continued.

\footnotetext{
DIATOMACHE:

Eumotia librile, Ehr.

Gallionella aurichalcea. Ehr.

Himantidium arcus, Ehr.

Navicula elongata, Ilal. ?

Odontella polymorpha, Ḱg.

Stauroneis maculata, B.

Surirella ovalis, Bréb.

Synedra vitrea, Kg.

" scalaris, Ehr.

Terpsinoü musica, Ehr.

Infesolis.

Amcba princeps, Ehr.
}

\author{
INFUSORIA. \\ Ircella vulgaris, Ehtr. \\ Brachionus polyacanthus, Ehr. \\ Culeps hirtus, khr. \\ Cothumia imberbis, Ehr. \\ Dinocharis tetractis, Elle. \\ Floscularia mmata, Whr. \\ Opereularia articulata, Goldf. \\ Oicistes erystallinus, Goldf. \\ Philodina erythropthalma, Golds. \\ liotifer vulgaris, schele. \\ Scaridium longicandum, Eir. \\ Vorticella nebulifera, Bory.
}

spongilla thuviatilis, is also abundant in Lake Monroc.

The species of Amphiprora, Bacillaria, Odontella, and Navicula, mentioned in this list, are decidedly marine forms, and have been found by me on the shores of the Atlantic. They also occur in estuaries; but I confess I was surprised to find them so far up the St. John's, and in company with such truly lacustrine forms as many of those above mentioned. To add to the curious mixture of marine and fresh-water species in Lake Monroe, I will mention that the lake abounds with Paludina vivipara, Say, Ampullaria depressa, Say, with Unios, and several other fresh-water molluses, and yet contains abundance of a living marine zoophyte (Campanularia,) and a large fish of the Ray family, called by the settlers a "Stingaree." A curious living crustacean, a species (probably new) of Sphæroma, also abounds here, and is very destructive to cypress logs, canoes, \&c. Many of the silicious forms above mentioned were found in the mud of the creeks leading from the immense sulphur springs near Lake Monroe, and neither the Diatomacer, nor the numerous fish which inhabit these waters, appear to dislike the sulphur waters. I daily saw hundreds of large gar-fish which assembled directly over "the boil" of one of these springs, as if it was their favorite resort; and I also noticed that the large Ampliprora pulchra, B., and the Navicula elongata, grew in great profusion in waters cliarged with sulphuretted hydrogen, as in the outlet of the Green Spring at Mr. Duval's.

SHELL PANKS OF ENTERPRISE, FTC,

The vast deposits of Auviatile shells which exist at Picolata, Volusia, and Enterprise, are of great geological interest. Enterprise and Volusia present bluffs and hills of forty and fifty feet in height, and extending half a mile or more 
from the river, which are literally composed of almost nothing else but well preserved shells of the Paludina vivipara, Say, Ampullaria depressa, Say, some undetermined species of Unio, Helix septemvolvis, Melania, and a few others. There is scarcely any mixture of earth, but the shells are clean, and look as if they had been washed ashore after the death of the animals. In some places the beds are sandy, and are hardening into a calcareous sandstone. In one such bed, the superficial stratum furnished a few bones of turtles and undetermined fragments, the bones of some large vertebrate animal. This is, I believe, the same locality where Count Pourtalés collected human bones in a recent sindstone. That the sandstone is recent $\mathrm{I}$ have no doubt, but the shells from which these banks are formed, thongh belonging to species now inhabiting the lake and river, were probably accumulated thonsands of years ago, under very different circumstances as to elevation, topograply, \&c., from those now existing. They certininly form the most remarkable fresh-water deposits in the United States. No microscopical forms were detected in these beds, after the most careful search.

PONDS NEAR ENTERPRISE, FA.

April 12th to 18th, 1-50.-In fresh-water ponds, near Mr. Duval's boarding honse at Enterprise, I found a most abundant supplyof interesting microscopical forms, among which the following were identified:

DESMIDIE.S.

Ankistrodesmus falcatus, Corda.

Aptogonum Baileyi, Ralfs.

desmidium, Ehr.

* Cosmarium depressum, B. Pl. 1, fig. I.

pyramidatum, Bréb.

Closterium lunula, Ehr.

$$
\text { “ setaccum, Ehr. }
$$

Didymocladon fureigerus, Ralfs.

* " cerberus, B. Pl. 1, figs. 15, 16.

* “ longispinum, B. Pl. 1, fig. 17.

Didymoprium Grevillii, Ralfs.

" Borreri, Ralfs.

*Docidium hirsutum, B. Pl. 1, figr. 8.

“ minutum, Ralfs. Pl. 1, fig. 3 .

“ undulatum, B. Pl. 1, fig. 2.

Euastrum ampullaceum, Ralfs.

“ clegans, Bréb.

“ insigne, Hass.

“ rostratum, Ralfs.

“ sublobatum, Bréb.

" verrucosum, Elır.

Hyalotheca dissiliens, Bréb.

Nicrasterias Baileyi, Ralfs.

* “ arcuata, B. Pl. 1, fig. 6 .

“ denticulata, Bréb.
* Nicrasterias expansa, B. Pl. I, fig. 7.

" fimbriata, Ralfs.

“ pinnatifida, $\mathrm{Kg}$.

* “ quadrata, B. Pl. 1, fig. 5.

“ rotata, Ralfs.

“ truncata, Bréb. Pl. 1, fig. 20.

Penium Jenneri, Ralfs.

$$
\text { margaritaceum, Bréb. }
$$

Sphærozosma exeavatum, Ralfs.

" serratum, $B$.

“ pulchrum, B.

Spirotænia eondcusata, Bréb.

Staurastrum aristiferum, Ralfs.

" gracile, Ralfs.

" margaritaceum, Ehr.

". tricorne, Bréb.

Triploceras verticillatum, Bréb. Pl. 1, fig. 9.

. gracile, B. Pl. 1, fig. 10.

Tetmemorus Rrebissonii, Ralfs.

Xanthidium armatum, Bréb.

“ fasciculatum, Ehr.

" octocorne, Ralfs.

*A porea ambigua, B. Pl. 3 , fig. 3. 
PONDS AT ENTELRRISL.-Contimued.

Intesinis

Arcella aculeata, Ehr.

Conochilus rolvox, Ehr. Pl. 3, lig. "2.

Dinobryon sertularia, Ehr.

Gonium glaucum, Ehr.

Hydatina senta, Ehl.

Lacinularia socialis, Elnr.

* Melicerta nuda, B. Pl. 3, figs. 8, 10.

ringens, Sclirank

*Peridinium carolinianum, B. P'. 3, figs. 4, 5 .

Philodina aculeata, Ehr.
Philodina restita, B. Pl. 3, figrs, 9 and 14.

Rotifer macrourus, kir.

“ pannosus, H. Pl. 3, figs. 6, 7.

“ vulgaris, Schlu.

Spirostomum ambiguum, Ehr.

Stephanoceros Eichhornii, Ehr.

* Diatoma stellaris, B.

'Tabellaria fenestratum, Ehr.

\section{SULPIIUR SPRINGS NEAR ENTERPRISE, ETC., FA.}

The enormous sulphur springs of Florida are among the most remarkable of the features of this interesting region. They are often from fifty to one liundred feet in diameter, and as many in depth, and pour out bold streams of sulphuretted water of such magnitude that large boats may proceed up them directly into the basins of the springs. The sulphur springs at Orange Spring, (Pearson's), the Blue Spring on the St. Joln's, and the Green Spring at Enterprise, are the most remarkable which I saw. In all of these I noticed immense quantities of an Oscillatoria which, I believe, is the O. terebriformis of Agardh, with the description of which in Kützing's Species Algarun, p. 239, it agrees perfectly. Its very active vermiform and spiral motions I observed very frequently while at Enterprise. It is accompanied at the springs by a white plant, generally more or less coated with sulphur, which appears to be the Beggiatora raineriana of Meneghini. (See Kützing, l. c. p 237.) In my notes I have recorded the following forms as found in Demaster's Sulphur Spring, "close to the Boil."”

Closterium acerosum, Schr.

* Amphiprora pulchra, $\mathbf{B}$.

Eunotia gibba, Ehr.

Navicula cuspidata, Kg.
Navicula elongata, (?)

Pinnularia viridis, Ehr.

Beggiatora raineriana, Menegh.

Oscillatoria terebriformis, $\mathrm{Ag}$

\section{ADDITIONAL OBSERVATIONS IN GEORGIA.}

On my return from Florida, I visited the interior of Georgia, hoping to have an opportunity of comparing the inland microscopical forms with those of the coast which I had previously studied. I was disappointed, however, by the alınost constant rains, which in the lilly or mountainous regions produced freshets which swept away everything living in the streams, or buried them in mud. I have, therefore, only to record the species noticed at two localities. 


\section{MACON, GA.}

May 6th, 1850.-In a mill-pond on the road to Brown's Mount, near Macon, Ga., I found the following species, viz:

DESMIDIEL.

Arthrodesmus convergens, Ehr.

Closterium moniliferum, Ehr.

Cusmatium mal'garitiferum, Menegh.

" ovale, Ralfs.

" pyramidatum, Bréb.

Desmidium quadrangulatum, Ralfs.

Didymocladon furciger'us, Ehr.

Euastrum elegaus, Bréb.

" rostratum, Ralfs.

" sublobatum, Bréb.

“ verrucosum, Ehr.

Micrasterias denticulata, Bréb.

“ furcata, $\Delta g$.

“ truncata, IBréb.

Pediastrum boryanum, Menegh.

“ heptactis, Mencgh.

“. ellipticum, Hassall.
Desmideat.

Pediastrum tetras, Ralfs

Penium digitus, Bréb.

*Spliarozosma serratum, li.

Staurastrum cyrtocerum, Bréb.

“ gracile, Ralfs.

IxFECORIA, ETC.

Arcella dentita, Ehr.

Dinobryon scrtularia, Ehr.

Euglena pleuronectes, Ehr.

Pterodina patina, Ehr.

Rotifer vulgaris, Schr.

A LG. E.

* Aporea ambigua, B.

Bulbochæte setigera, $A g$.

A'THENS, GA.

The following species were collected on the 20th of May, near Athens, Ga. viz:

\section{Desuidie.c.}

Clostcrium lunnla, Ehr.

" monilifornc, Ehr.

“ turgidum, Ehr.

Desmidium Swartzii, $\Lambda \mathrm{g}$.

Didymocladon furcigerns, Ralfs,

Docidium clavatum, Kütz.

Euastrum oblongrum, Ralfs.

$$
\text { ، verrucosum, Ehr. }
$$

Micrasterias papillifera, Bréb.

$$
\text { " pinnatifida, Ehr. }
$$

Penium digitus, Ehr.

Staurastrum orbiculare, Ehr.
DESṂDIE.E.

Staurastrum muticum, Bréb.

Spirotrenia condensata, Bréb.

INFUSOR1A, ETC.

Amceba princeps.

A rcella angulata.

Cocconema cymbiforme.

Difflugia proteiformis.

* “ spiralis, B.

Pinuularia viridis, Elır. 


\section{NORTHERN LOCALITY, NEAR PROVIDENCE, IR, I.}

For the sake of comparison with the above lists of Southern forms, I give here the names of the species noticed by me in Wainskut Pond, near Providence, R. I., on the 18th of July, 1850.

DEsmidie.e.

Ankistrodesmus falcatus, Corda.

Arthrodesmus convergens, Ehr.

Cosnarium orale, Ralfs.

" undulatum, Corda.

Closterium Dianxe, Ehr.

" angustatum, Kig.

" lineatum, Ehr.

“ Jenneri, Ralfs.

" moniliferum, Elır.

Docidium nodulosum, Bréb.

Desmidiun Swartzii, Ag.

" quadrangulatum, Ralfs.

Didymoprium Borreri, Ralfs.

Euastrum ansatum, Ehr.

" circulare, Hass.

، didelta, Ralfs.

" elegans, Bréb.

“ gemmatum, Kg.

" oblongum, Ralfs.

“ rostratum, Ralfs.

" verrucosum, Ehr.

Hyalotheca dissiliens, Bréb.

Micrasterias pinnatifida, Kg.

" truncata, Bréb.

“ denticulata, Bréb.

" rotata, Ralfs.

Penium digitus, Bréb.

" margaritaceum, Bréb.

Pediastrum pertusum, Kg.

" boryanum, Menegh.

" ellipticum, Hass.

" heptactis, Menegl.

" tetras, Ralfs.

“ selenæa, Kg.
Desminde.t.

- Scenedesmus obliquus, Kóg.

" obtusus, Meyen.

" quadricauda, Bréb.

Sphrerozosma excavatum, Ralfs.

Staurasłrum alternans, Bréb.

" gracile, Ralfs.

" lirsutum, Ehr.

Spirotænia condensata, Bréb.

'T'etmemorus Brebissonii, Ralfs.

Xanthidium fasciculatum, Ehr.

\section{Diatomace.a.}

*Diatoma stellaris, $B$.

Eunotia serra, Elır.

Himantidiun arcus, Ehr.

Gomphonema acuminata, Elır.

Tabellaria flocculosa, Ehr.

"f fenestrata, Elır.

INFUSORIA.

Arcella vulgaris, Ehr.

Brachionus Bakeri, Ehr.

Coleps hirtus, Ehr.

Difflugia protciformis, Ehr.

"spiralis, B.

Dinobryon sertularia, Ehr.

Euglena viridis, Ehr.

" pleuronectes, Ehr.

Floscularia ornata, Ehr.

Melicerta ringens, Schr.

Peridinium cinctum, Ehr.

Rotifer macrourus, Ehr.

" vulgaris, Ehr.

Stentor polymorphus, Ehr.

See also in the Appendix a list of forms found near Salem, Mass., by Thomas Cole, Esq.

By consulting the above lists, the species found at each locality will be seen. The following tables will show the same in a more condensed form, and will also exhibit the geographical distribution of species. 
'T A B I, li A.

SHOWING TIE GEOGRAPIICAL DISTIBUUTON OF THE SPECIES OF DESMIDIEA INQIUDED IN THE PRECEDING IISTS. TIIEIR OCCURRENCE AT ANY LOCALITY IS INDIC:ATED BY +.

\section{NAMES OF SPECIET}

Species marked with * are believed to be new, and are described at page 36 .

\section{Localities.}

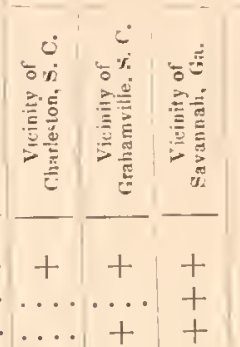

Ankistrodesmus falcatus, Colda.

Aptogonum Baileyi, Ralfs....

Arthrodesmus convergens, Ehr.

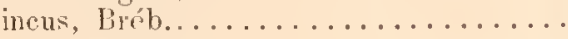

Closterium acerosum, Schr. .

amblyonema, Ehr.

angustatum, Kg.

Dianre, Ehur.

Ehrenbergii, Menegh.

Jenneri, Ralts

lanceolatum, lig..

Leiblenii, Kig.

lunula, Ehr.

moniliferum, Ehr.

setaceum, Ehr.

turgidum, Ehr.

Cosmarium amoenum, Bréb...

Broomeii, Thwaites,

connatum, Breb.

eucumis, Corda.................... +

depressa, B. Pl. 1, fig. 1, . . . . . . . . . . . .

margaritiferum, Nenegh

ornatum, Ralfs.

ovale, Ralfs.

pyramidatum. Bréb...................

Thu witesii, Ralfs.

undulatum, Corda.

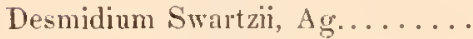

quadrangulatum, Ralfs.

Didymocladon furcigerus, Ralts.

cerberus, B. Pl. 1, figs. $15,16, \ldots \ldots \ldots \ldots \ldots \ldots$

* “ longispinus, B. Pl. 1, fig. 17,.

Didymoprium Burreri. Ralfs.

Grevillii, Ralfs.

Docidium baculum, Bréb

clavatum, Kg..

constrictum, B.

Ehrenbergii, Ralfs................

hirsutum, B. Pl. 1, fig. $8, \ldots \ldots \ldots \ldots \ldots \ldots$

minutum, Ralfs. Pl. 1, fig. $3, \ldots \ldots \ldots \ldots \ldots \ldots+$

nodosum, B. Pl. 1, fig. $4, \ldots \ldots \ldots \ldots \ldots \ldots \ldots+$

nodulosum, Bréb............... $+\ldots+\ldots$

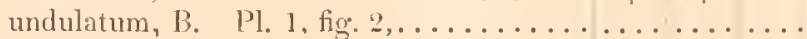

Euastrum affine, Ralfs.

$$
\text { verrucosum, } \mathrm{B} \text {. }
$$

anpullaceum, Ralf

ansitum, Ehr.

hinale, Fhr.

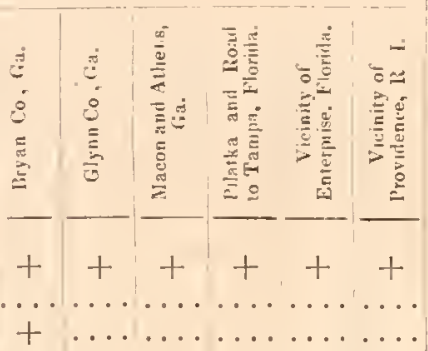

$+\ldots+\ldots+\ldots+$

$+\ldots \ldots \ldots+\ldots \ldots$

$+\ldots \ldots+\ldots+\ldots$

$\ldots \ldots \ldots \ldots+$

$+\ldots+\ldots+$

$\ddot{+}+\ldots \ldots+\cdots+\ldots+$

$\ldots \ldots \ldots \ldots+$

$+\ldots \ldots \ldots \ldots$

$\ldots \ldots \ldots+$

$+\ldots \ldots+\ldots$

$+\ldots \ldots \ldots+$

$+\ldots+\ldots \ldots+\ldots+$

$\ldots \ldots \ldots \ldots+\ldots+$

$\ldots \ldots \ldots \ldots \ldots+\ldots \ldots$

$+\ldots \ldots \ldots \ldots \ldots \ldots$

$\ldots \ldots \ldots \ldots+\ldots \ldots+\ldots$

$\ldots \ldots \ldots+\ldots+\ldots$

$+\ldots \ldots$ 
Table A.-Contimed.

Inc.uLitie.

NAMES OF SPEOIES.

Euastrum circulare, Hass.

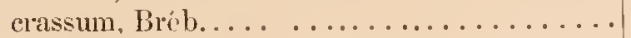

didelta, Ralfs.

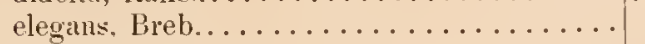

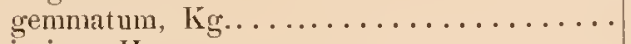

insigre, Hass.

muricatum, B.

oblongum, Ralfs.

rostratum, Ralfs.

sublobatum, Bréb.

" vermcosum, Ehr.

Hyalotheca dissiliens, Bréb. ..........

* Licrasterias arcuata, $B$. Pl. 1 , fig. $6, \ldots \ldots \ldots \ldots \ldots$

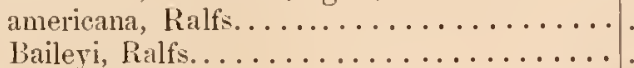

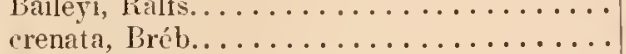

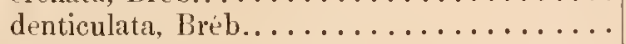

* “ expansa, B. Pl. 1, fig. $7, \ldots \ldots \ldots \ldots \ldots \ldots$

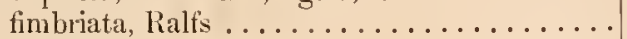

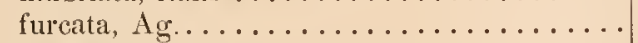

incisa, Kig. Pl. I, fig. $13, \ldots \ldots \ldots \ldots \ldots \ldots \ldots$
oscitans, Ralfs. Pl. 1, fig. $19, \ldots \ldots \ldots \ldots \ldots$

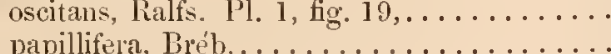

pinnatifida, Irg.

* “ quadrata, $\mathrm{B}$.

Pl. 1, fig. 12, .

ringens, $\mathrm{B}$. $\mathrm{P} \mid \mathrm{i}, \mathrm{fig} .1 \mathrm{1}, \ldots \ldots \ldots \ldots \ldots \ldots \ldots$

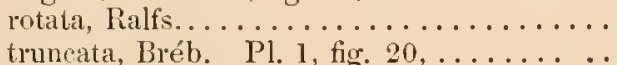

Pediastım boryanum, Menegh. . .............

ellipticum, Hass...................

heptactis, Mcncglı................

napoleonis, Menegh . .............

pertusum, lig.

scienæa, $\mathrm{Kg}$.

tet las, Raifs

Penium Brebissonii, Ralfs... .

closteroides, Ralfs.

digitus, Ralfs..........

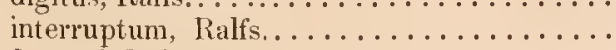

Jenneri, Ralfs.

margaritaccum, Bréb.

Scenedesmus aculus, Meyen,

obliquus, Kg. .

obtusus, Meyen,...

quadricauda, Bréb.

Spharozosma cxcavatum, Ralfs.

pulchrum, B..................

* “ serratum, B. Pl. 1 , fig. $14, \ldots \ldots \ldots \ldots \ldots$

Spirotænia condensata, Bréb.

Staulastrum alteruans, Bréb. aristiferum, Ralfs. cyrtncerum. Brób.

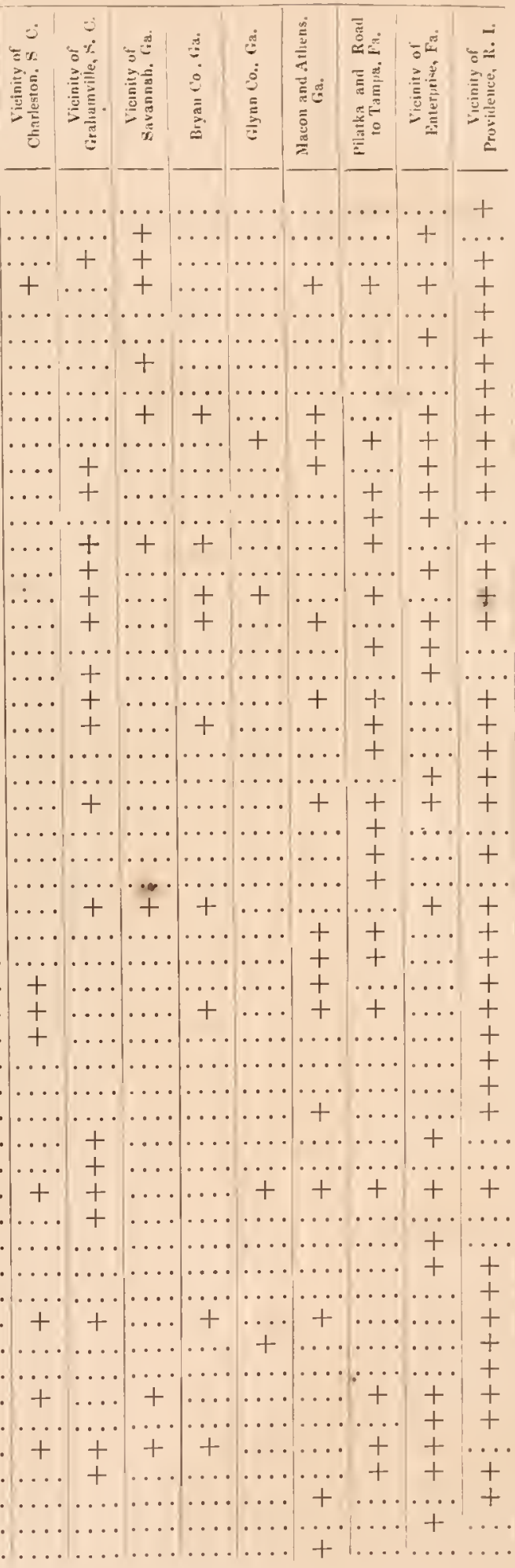


TABLE A.-Continued.

NAMES OF SPECIES.

Staurastrum dejectum, Brób.

enolme, Ralfs. Pl. 1 , fig. 18 ,

gracile, Ralfs

Loc.hLtrie:

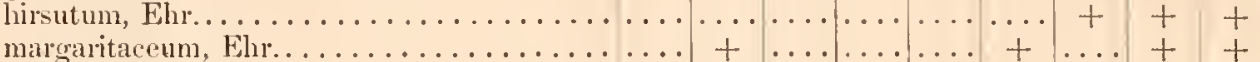

$+\cdots++$

orbiculare, Ehr..........................................

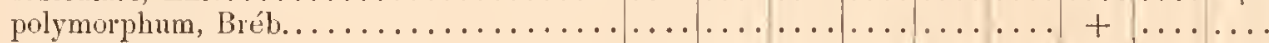

tricone, Bréb...............................

Tetmemorus Brebissonii, Ralfs.................. $\ldots \ldots+\ldots \ldots \ldots \ldots+\ldots+$

"granulatus, Ralfs. ................... $\ldots \ldots \ldots \ldots \ldots \ldots \ldots$

*Triploceras verticillatum, B. Pl. 1, fig. 9, ............

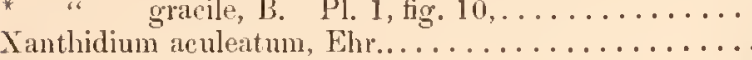

Xanthidium aculeatum, Ehr.

- cristatum, Bréb....................

" fasciculatum, Ehr..................

" octocorne, Ralfs.

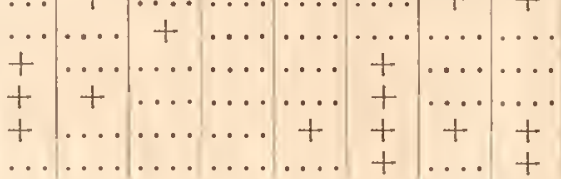

Full descriptions and accurate figures of all these except the new ones marked witlı *, may be found in Ralfs' beautiful volume, tlıe "Britislı Desmidieæ." 
'T A B L E B.

SHOWING TIE GEOGRAPIICAL DISTRIBUTION OF TIE SPLCILS OF DIATOMACLA; INCLUDED IN TILE PRECEDING LISTS.

\section{NAMES OF SPECIES.}

N. B. The species in the columns marked $F$ were found in fresh water having no communiention with the ocean; those in the columus marked $M$ were either found in salt water, or in localities lraving a connection more or less remote with the ocean.

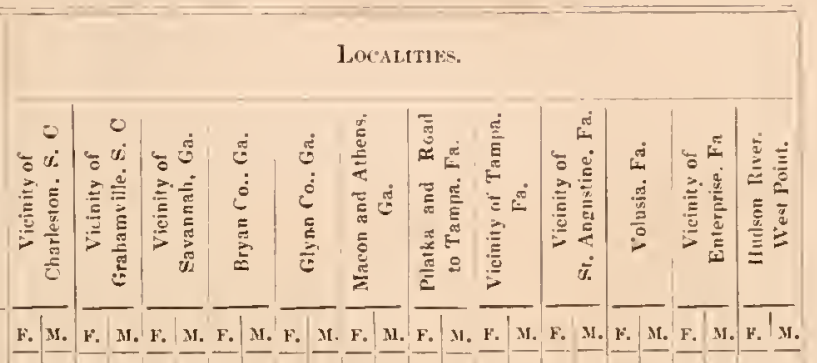

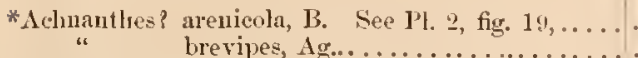

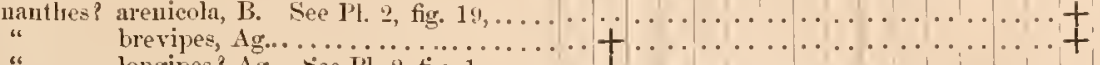

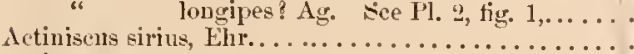

Actinocychus bioctonarius, Elır.

Actineptycluns senarius, Ehr...................

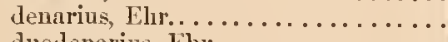

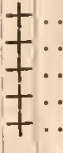

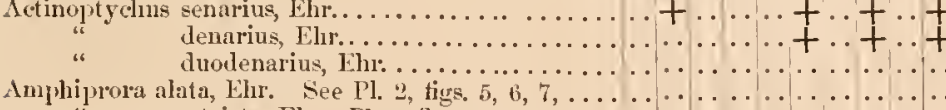

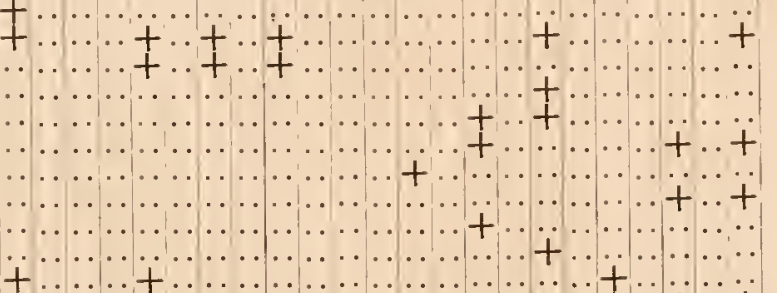

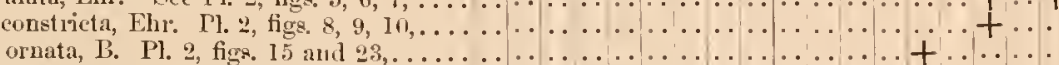
pulchra, B. I'l. 2 , figs. 16 and 18, . quadrifasciata, $B$. P'l. 2 , fige. $2,3,4$ libyea,

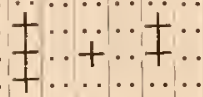

Biddulplia pulchella, Gray....................

*Canpylodiseus argus, B. Pl. 2, figs. $24,25, \ldots \ldots \ldots$ clypens, Ehr.

*Cerataulus tuigidus, Ehr. Pl. 2 , figs. $26,27, \ldots \ldots \ldots$

Ceratone is elosterium, Ehr. 1'l. 2, fig. $17, \ldots$ firsciola, Ehr. ...................

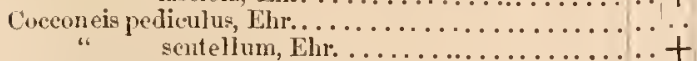

Coconema cymbiforme, Elir.

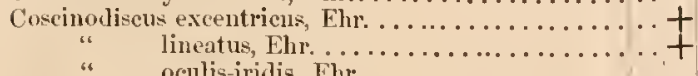

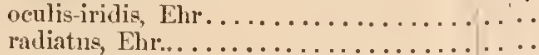
subtilis, Ehr. . . . . . . . . . . . . . . . . . .

Denticella? tridentata, Ehr.(_-Zygoceros Tuomeyi, Bailey,).

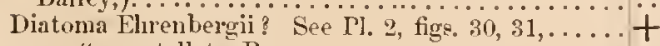
stellata, B.

Inictyoclaa fibula, Ehr.

Eunotia amplnioxys, El

$$
\begin{aligned}
& \text { gibba, Ehr.. } \\
& \text { hibrile, Ehr. }
\end{aligned}
$$

$$
\text { nodosa, } \mathrm{Kg} . \text {. }
$$

tetraodon, Ehr..

Fupodiseus Baileyi, Ehr..

$$
\text { Rogersii, Ehr. }
$$

Fragilliria pectinalis, Ehr. .

Fallionella aurichalcea, Ehr.

" suleata, Ehr.

rarians, Ehr. (i. arenaria, iloore, )...

fomphonema acuminatum, Elir.

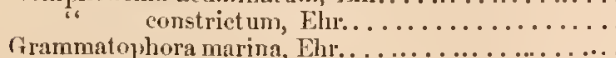

Ilimantidium arcus,

Lirmophor bidens, Elır...

$$
\text { bidens, Elir.. }
$$

Saunema, mudetermined, ......
Savieula amphigompha, Ehr..

amphirhynehus, Ehr.....................

loaltiea...

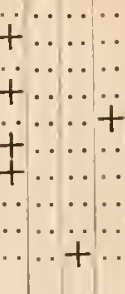

$\ldots+$

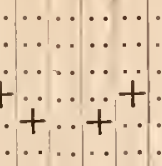

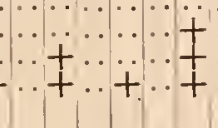

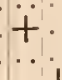

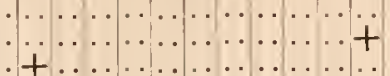

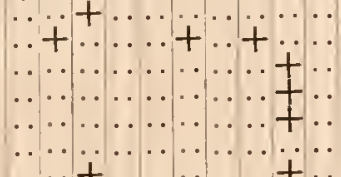

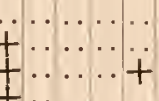

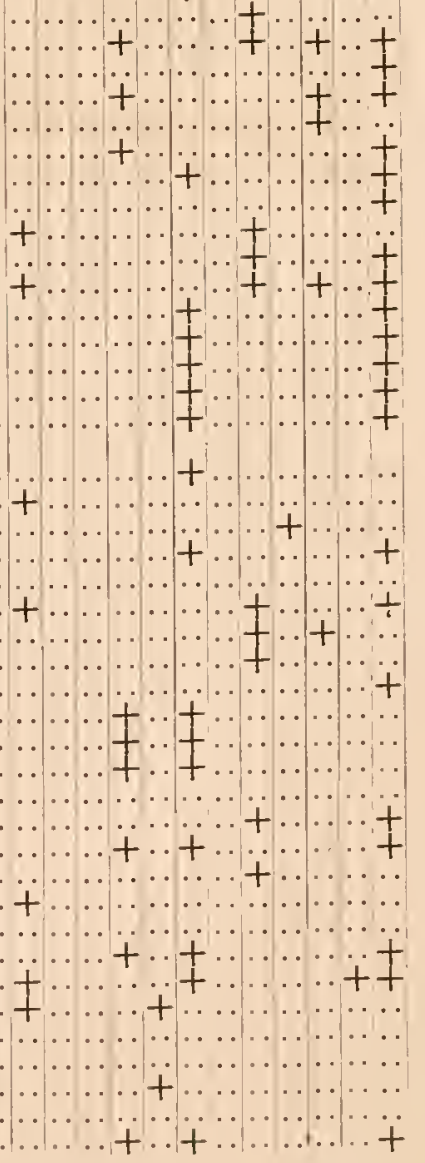




\section{Tabee B.-Comtimed.}

NAME OF SPlECIES

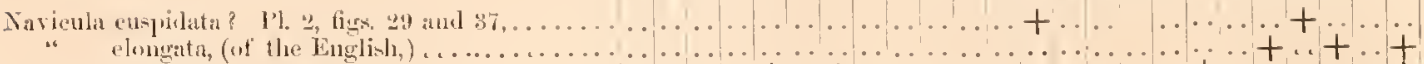

\begin{tabular}{|c|c|c|c|c|c|c|c|c|c|c|}
\hline & & & & Loc.II & I CIE: & & & & & \\
\hline 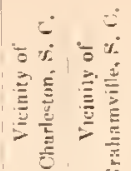 & 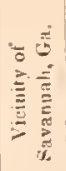 & 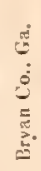 & 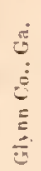 & 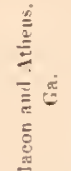 & 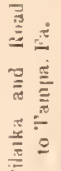 & 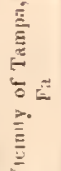 & 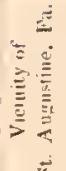 & 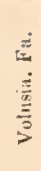 & 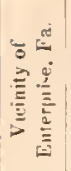 & \\
\hline
\end{tabular}

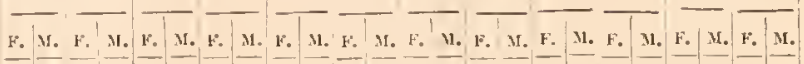

$\pm=-\frac{1}{2}-1$

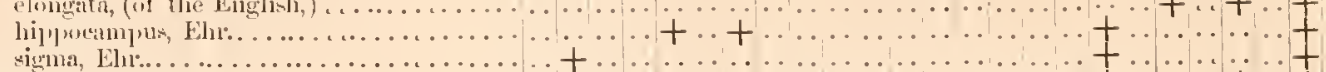

Odontella polynorplia, Kig..

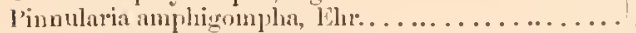
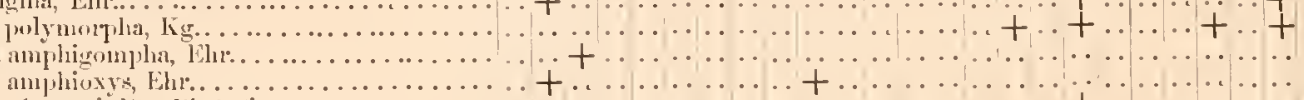

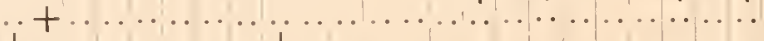

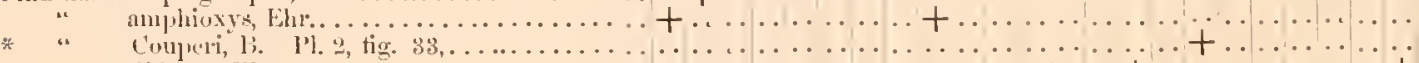

$" \quad$ dilyma, LIr...........................................

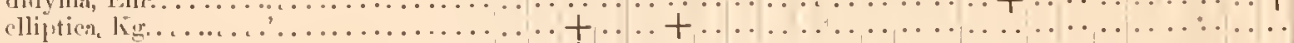

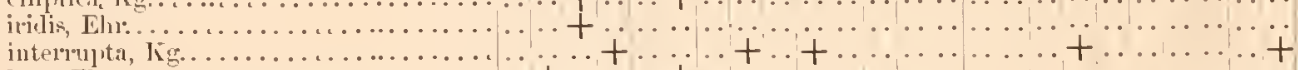

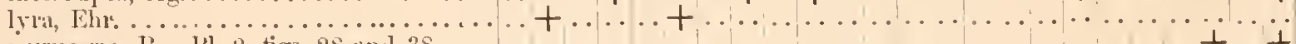

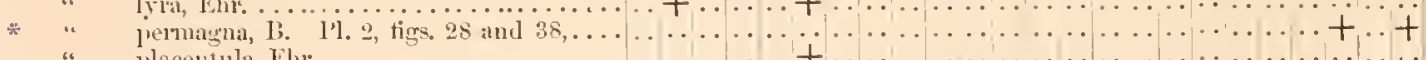

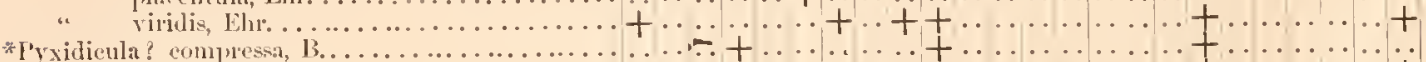

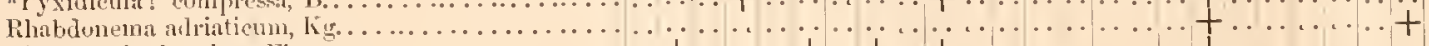

Rhaphoneis rhombus, Ehr..

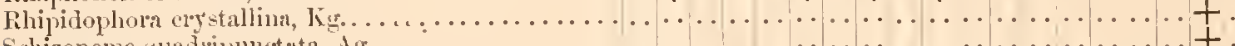

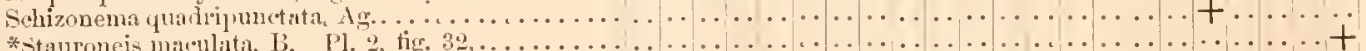

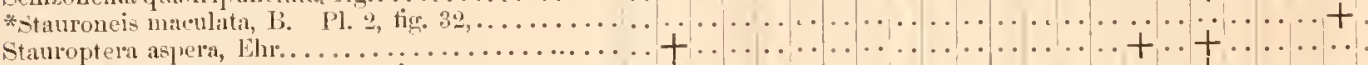

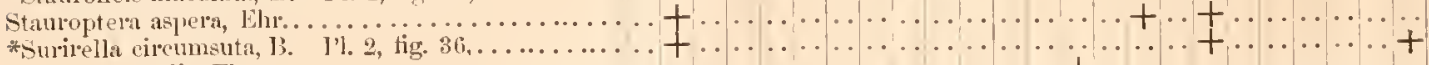

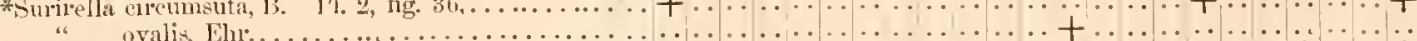

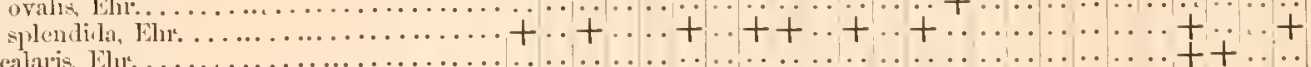

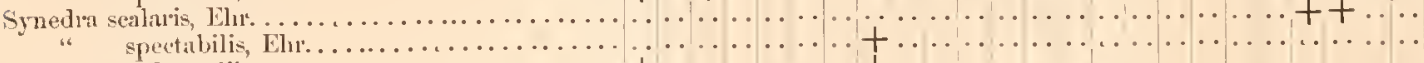

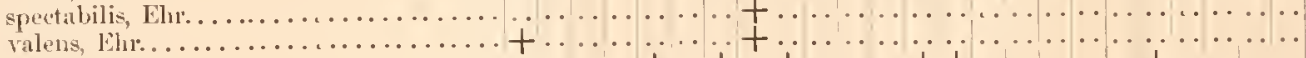
vitrea, K..............................

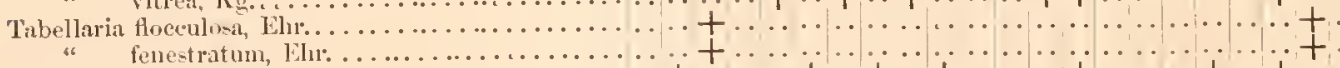

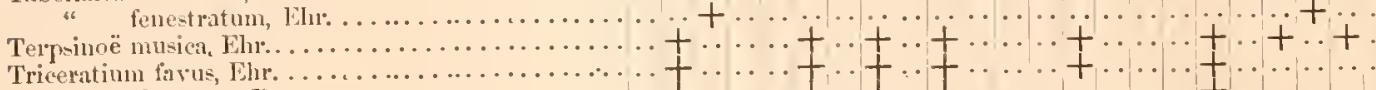

alternaus, $\mathrm{B}$.

obtusum, Elır,

reticulum, Elur.

*Zygoceros (Denticella? ) Mobilensis, B. Pl. ㄹ, tign. $3 \pm$ and 35

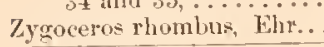

Such of the above species as are not indicated as new, will be found described in Ehrenberg's "Verbreitung und Einfluss des mik, I.ebens in S. und N. America," and in Kütring's "Bacillarien, oder Diatomeen." For a description of the new species, see page 38 . 
'T A B L E C .

SHOWING TIE GEOGRAPHICAL DISTRIBUTION OF TIE INFUSORIA INCLUDED IN TIIE PIRELDIXG LIS'TS.

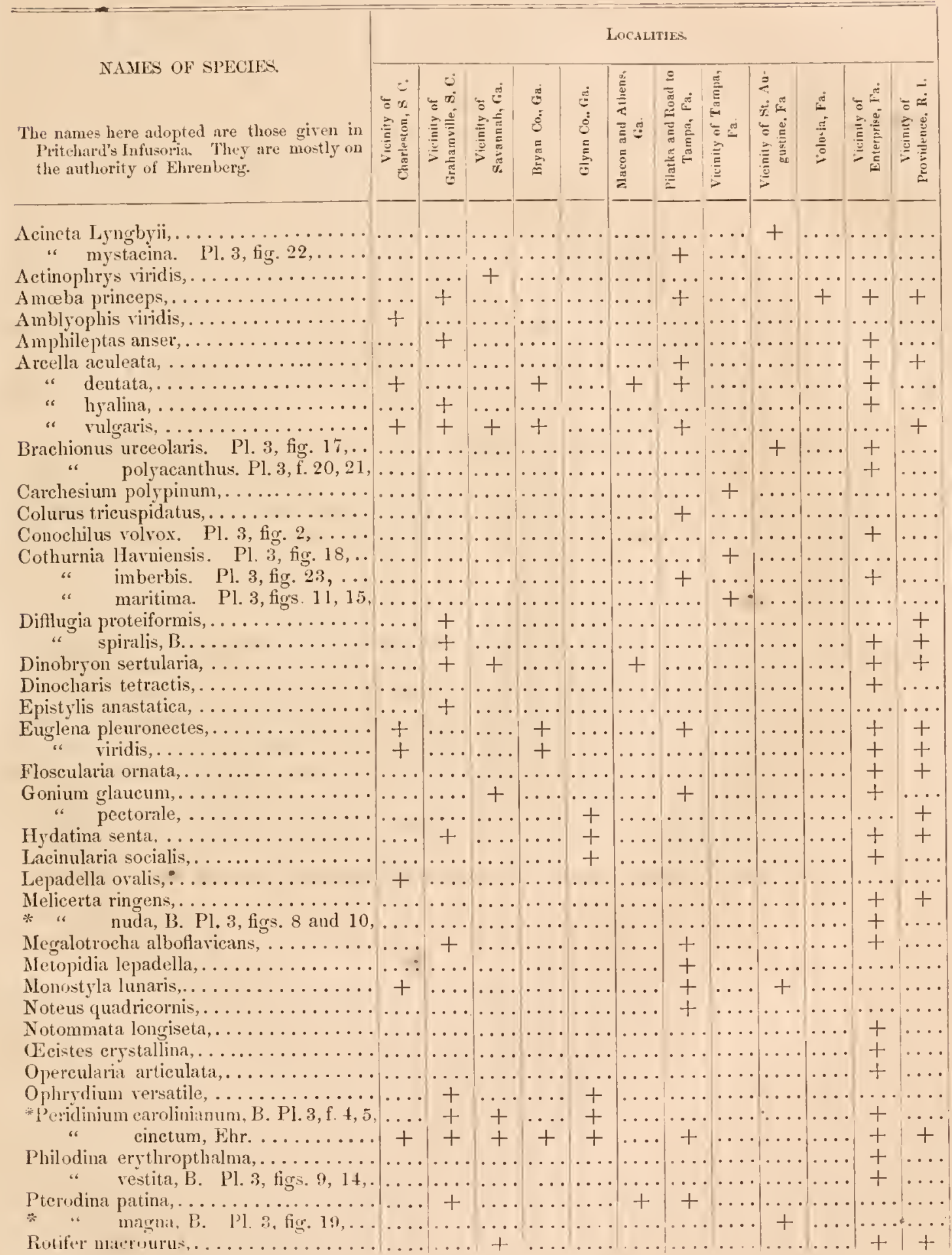


Table C.--Continued.

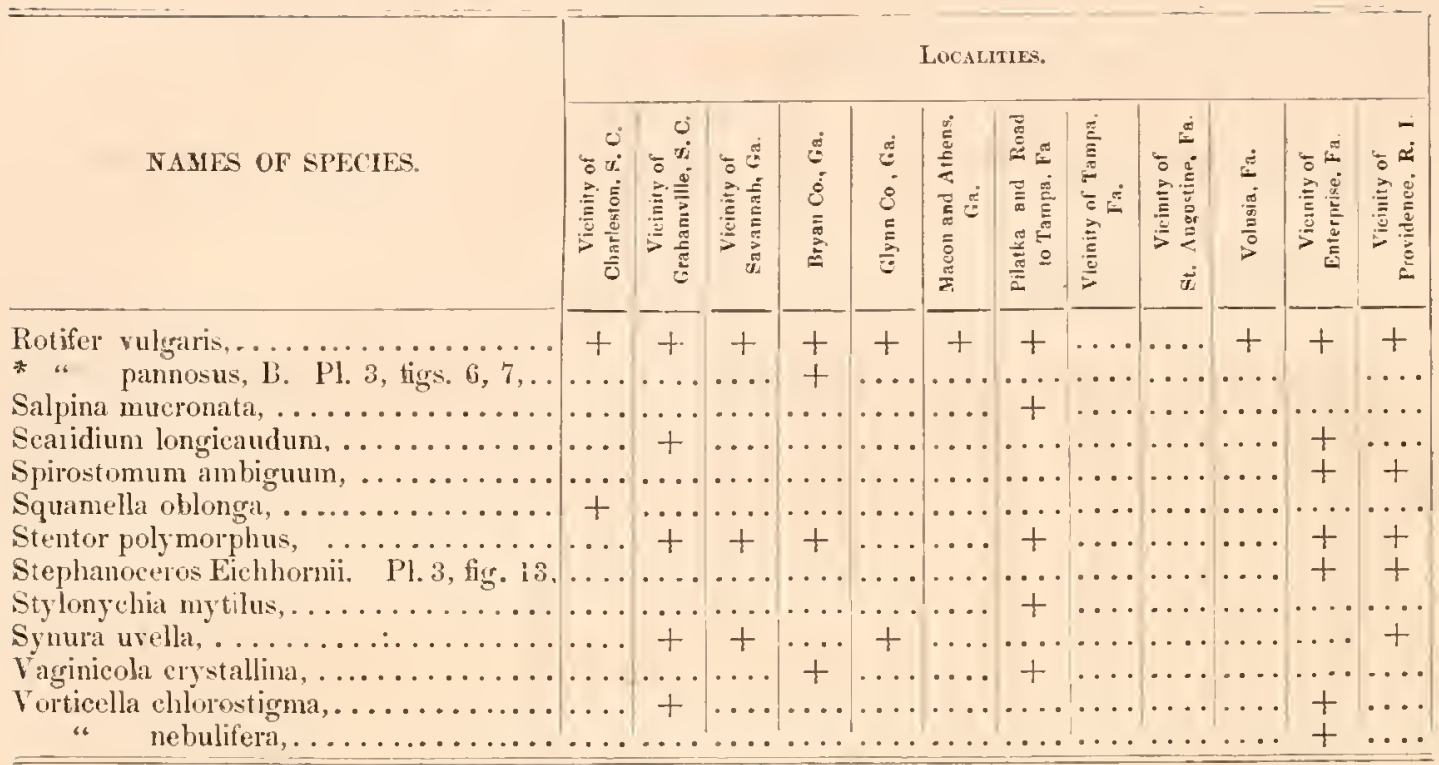

Descriptions of most of the above species, with figures and copious lists of synonyms, may be found in Ehrenberg's splendid volumes, "Die Infusionthierchen," and accounts abridged from the same work are given in Pritchard's "Infusoria, Living and Fossil." The latter work was the one I had with me in my Southern tour.

Note. In the preceding tables I have separated the Desmidiere and Diatomacere from the Infusoria, and I have done so because many distinguished observers now consider these groups as decidedly belonging to the vegetable kingdom. While I believe that no accurate line of separation can be drawn between regetables and aninals, I am yet disposed to consider the Desmidica, from the sum of all their characters, as most nearly allied to admitted regretables, while the Diatomacese, notwithstanding Thwaites' interesting observations on their conjugation, still seem to me, as they have always done, to be true animals. 'There is such apparent volition in their movements, such an abundance of nitrogen in the composition of their soft parts, and such resemblances between the stipitate Gomphonematre, and some of the Vorticellæ, that 1 should still be disposed to class them as animals, even if Ehrenberg's observations of the retractile threads and snail-like feet of some of the Naviculæ should not be confirmed. 


\section{'T A B L F D.}

\section{LIST OF ALGA REFERIRE TO IN TIF PIRGSDING PAGES, WITII LOCALITIES.}

A porea ambigua, B Occurs everywhere in the lakes and ditches of the Southern States. Bangia fusco-purpurea, Dillw. Tampa, Fa.

Batrachospermum moniliforme, Roth. Big Hillsborough River, Fa.

Botrydium argillaceum, Wall. Near Savannilh, Ga.

Bulbochre setigera, Ag. Common throughout the United States.

Ceramium clavulatum, Ag. Tampa.

Chætopliora pisiformis, Ag. Common.

Coleochæete scutata, Bréb. In lakes, de., from Massachusetts to Florida. Very abundant in a pond on Anastasia Island, near St. Augustine.

Delesseria hypoglossum. Near Wilmington, N. C., Clarleston, S. C., and St. Augustine, Fa.

“ Leprieurii, Mont. An estuary species found first in Cayenne, South America, afterwards in the Hudson River, at West Point, N. Y., and on this tour in the Ashley, Savamah, Ogeechee, Altamaha, St. Sebastian, and Hillsborough rivers, usually accompanied by a large species of Bostrichia.

Ectocarpus littoralis, L. Common.

Gelidium corneum, Huds. St. Augustine.

Gracilaria multipartita, Clem. St. Augustine and Tampa.

Laurencia dasyphylla, Woodw. St. Augustine.

Mougeotia genuflexa, Ag. Hopeton, Ga., Warm Springs and St. Augustine, Fa.

Oscillatoria terebriformis, Ag. Abounds in the sulphur springs of Florida, and in the streams issuing from them. The motion of the filaments is very active.

Polysiphonia Olneyi? Harv. Tampa.

Porphyra vulgaris, Ag. Charleston, S. C., St. Augustine, Fa.

Rhabdonia Baileyi, Harv. Very large specimens are common at St. Augustine.

Sargassum vulgare, Ag. Tampa.

$\underset{\text { Spirogyra, (Zygnema, Ag.) quinina, Kg. }}{\text { decimina, } \mathrm{Kg} \text {. }}$ Common everywhere.

Spiridia filamentosa, Wulf.

Tetraspora lubrica, Ag. Grahamville, S. C.

Vaucheria cespitosa, D. C. Common.

" racemosa. Near Savanuah, Ga.

Ulva latissima, $\mathrm{L}$. 


\section{E S C R I P T I O N}

OF THE NEW SPECIES, REFERRED TO IN THE PIRCEDING H.ISTS.

\section{DES M I D I E F.}

1. Cosmarium nepressum, B. Pl. 1, fig. 1. Elliptical, binate, division in the plane of the longest axis. Segments entire, nearly twice as long as broad, rounded above, very much flattened at base.

Hab. Lakes in Florida.

'I'his species resembles C. bioculatum, Bréb., but the segments are much closer together, and are angular, not rounded at the basal extrenities.

2. Didymoclanon? cerrmers, B. Pl. 1, fig. 15 and 16. Small, deeply constricted, segments three-lobed, lobes with four teeth, two of which project upwards and two downwards at each truncated angle.

IIab. Lakes in Florida.

3. Dinyochanon? conuisprnum, B. Pl. 1, fig. 17. Large, smooth, triangular, with two long spines at each angle.

Hab. Lakes in Florida.

The two last species are not very nearly allied to each other, nor to the typical D. furcigerus, yet they agree better witl the verbal characters of the genus than with those of any other known to me; I therefore refer them here provisionally.

4. Docidun hirscrom, B. Pl. 1, fig. 8. Segments many times longer than broad, slightly inflated at base, surface hirsute.

A small species resembling D. Ehrenbergii in form, but strongly hirsute on its outer surface.

Hab. Lakes in Florida, at Enterprise.

5. Docidiun undulatum, B. Pl. 1, fig. 2. Segments eight to ten times longer than broad, constricted six to eight times at regular intervals throughout their entire length, with the base and ends crenate.

Sinaller than D. nodulosum, Bréb., with more frequent and deeper constrictions. The same characters distinguish it from D. nodosum and D. constrictum, B. 
6. Micrasterins arcuata, B. Pl. 1, fig.6. Quadrangular, segments three-lobed, the basal lobes long and arcuate, subtended by the transverse projections fiom the ends of the slightly notched terninal lobes.

An interesting and very distinct species, which can be confounded with no other except the following.

Hab. Lakes in Florida.

7. Micrasterias expansa, B. Pl. 1, fig. 7. Segments three-lobed, basal lobes long, sub-conical, acute; terminal lobes slender, forked at the end, with the divisions much shorter than the basal lobes.

This somewhat resembles the preceding species, with which it occurs, but I have seen no internediate forms, out of many hundreds of each, and the characters above given appear sufficient to separate them.

Hab. Lakes in Florida, at Pilatka and Enterprise.

8. Mrerasteinas quadrata, B. Pl. 1, fig. 5. Large, quadrangular, three-lobed, basal lobes elongated, slightly curved, bidentate; terminal lobes with two slender transverse bidentate projections.

Its larger size and distinctly bidentate projections sufficiently distinguish it from the two preceding species.

Hab. Lakes in Florida.

9. Micrastertas rivines, B. Pl. 1, fig. 11. Oblong, segments three-lobed, coarsely granulated near the edge ; basal lobes subdivided by a deep notch into two rather broad and obtuse or slightly bidentate projections; terminal lobes exserted, emarginate ; extremities bidentate or obtuse.

Resembles M. Baileyi, Ralfs, but is larger, its divisions less slender, and with the granulations differently placed.

Lakes in Florida, near Dade's Battle Ground.

10. Spinfrozosma serratum, B. Pl. I, fig. 14. Joints broader than long, deeply notched or divided into two transverse portions with acute projecting ends, which give a serrated outline to the chain.

Common in fiesh water in South Carolina, Georgia, and Florida.

\section{Triploceras, nov. gen.}

Frond binate; segments straight, much elongated, with numerous whorls of knot-like projections; ends of the segments three-lobed; lobes bidentate.

A genus closely allied to Docidium, but differing in the three-parted ends of the segments. Pl. 1, fig. ?.

11. 'Trupoceras vertichlatum, (Bailey in lit. cum icone 1847, v. Brit. Desmid. p. 219) Robust, with whorls of emarginate projections. Syn. Docidium verticillatum, Ralfs. l. c. p. 219 , Pl. 35 , fig. $9 a, b, d, e$.

Hab. same as next species. 
12. Tiriploceras araciee, B. Pl. 1, fig. 10. Slender, with whorls of rounded projections. Ralfs, l. c. Fig. 9, $c$.

I discovered these forms in Rhode Island, in 1847, and sent sketches of them to Ralfs, who lias publishred an account of them in his British Desmidiex, p. 219. I then included both forms under the same name, but as I have now seen great numbers of each kind, I think them sufficiently distinct to be separated.

Hab. Worden's Pond, R. I., Princeton, N. J., Georgia and Florida. Abundant in lakes near Enterprise, Fa.

\section{I A TO M A C E R.}

1. Acinanties? alenicona, B. Pl. 2, fig. 19. Frustules minute, rectangular, or slightly curved; end view lanceolate, striate.

Small plates, composed of two or three frustules, supported by a short pedicel, were found abundantly on grains of the beach sand, below high-water mark, at Fort Brooke, Tampa. It is possibly a species of Hyaloseira, but requires further study.

2. Ampinprora pulcirna, B. Pl. 2, figs 16 and 18. Large, deeply constricted, ends rounded, sides compressed, carinate, distinctly striate, and near the margin punctate. Central portion narrow, sigmoid, with a few fine longitudinal lines. Often contorted so as to bring one lialf into a plane at right angles to the otlıer.

Hab. Beach at Rockaway, Long Island; lludson River, at Washington's Valley, near West Point, and in great abundance and of large size at Enterprise, Fa. The figures were drawn from Florida specimens collected in the mud of a small creek near Mr. Duval's boarding-house, at Enterprise.

3. Ampinprora orvata, B. Pl. 2, figs. 15 and 23. Small, deeply constricted, ends truncated and rounded, sides marked with a longitudinal row of undulations or pinnula, as in Surirella. Often contorted.

The rufle-like rows of pinnulie distinguish this species from all others. It probably las minute stria also, but I did not have an opportunity to examine with high powers.

Hab. Withlacoochee River, where it is crossed by the road from Pilatka to Tampa, Fa.

4. Ampinprora quadrifasciata, B. Pl. 2, figs. 2, 3, 4. Small, moderately constricted, ends truncate or sliglitly rounded, sides compressed or carinate, lanceolate, with the apices produced and rostellate.

When living, each specimen was marked by four transverse yellow bands. A high power shows the surface to be very millutely striate. No contorted specimens were seen.

Hab. 'Tampa, and St. Augustine, Fa. 
5. Anphora nuphoxys, B. Pl. 2, figs. 20, 21, 22. Ventral side rectangular, with slightly rounded ends, and two arcuate bands of strie, which are broadest near the centre. Back convex, minutely striate. Sides convex above, minutely striate, concave below, strongly striate. Ends produced and rostellite.

The side view of this species bears a striking resemblance to Eunotia amphioxys, Ehr.

Hab. St. Anastasia Island, near St. Augustine, Fa.

6. Campromiscus argus, B. Pl. 2, figs. 24, 25. Large, circular, and saddleshaped, surface marked with rows of conspicuous dots; margin smooth, with a row of pinnulie placed at a short distance from its edge.

A fine, large, and very distinct species, which appears to be widely diffused in the estuaries of the United States. I first found it, several years ago, in the mud of the IHudson River, at West Point, and in mud from the harbor of New Haven, Conn. In Florida I found it at St. Augustine, Tampa, and quite abundant at Enterprise. I also noticed it at IIopeton, on the Altamaha, in Georgin, and the mud from near New Orleans.

7. Cerataulus turgidus, Ehr. Pl. 2, figs. 26, 27. Frustules globular, or slightly compressed, with two large rounded prominences at each end, cohering by alternate angles, forming zigzag chains. Between the two rounded processes, and in a plane at right angles to that containing them, are placed two long hornlike processes.

'Two frustules are often connected by an external decussately punctate cell, as in Isthmia and Biddulphia. I first noticed this species at Rockaway, N. J., in the year 1843, and sent it to Ehrenberg, who informed me that he had named it Cerataulus turgidus.

I am not aware that any description of it has heretofore been published.

I found it at Tampa ; and it also occurs in the Hudson River, at West Point.

8. Diatoma stelianis, B. Frustules rectangular, many times longer than broad, usually in groups of five or six individuals, cohering by the adjacent (not alternate) angles, so as to produce a stellate arrangement. These stellate groups of minute frustules are so common from Rhode Island to Florida, that I am inclined to believe them a distinct species of Diatoma, and have accordingly referred to them by the name of $\mathrm{D}$. stellaris in the preceding pages.

9. Eupodiscus radiatus, B. In form, size, and reticulation resembling the Coscinodiscus radiatus of Ehrenberg, but having four (or more?) foot-like projections near the margin.

A common form in the Southern States.

10. Pinnularia Coupern, B. P1. 2, fig. 33. Large, slightly constricted in the middle, with two marginal and two intermediate punctato-striate bands, the latter interrupted at the centre. 
The outline is like that of P. paradoxa, Elır, and the markings somewhat resemble those of $P$. lyra.

Hab. St. Augustine.

I take great pleasure in dedicating it to James Hamilton Couper, Esq., of Hopeton, whose scientilic attainments and generous hospitality are well known to naturalists.

11. Pinvularia permagna, B. Pl. 2, figs. 28 and 38. Large, lanceolate on the ventral faces, with punctato-striate marginal bands, and a broad, smooth central stripe; ends slightly rounded.

Abundant in the Hudson River, at West Point, and occurs, of a smaller size, and much less abundantly, in Lake Monroe, at Enterprise, Fa.

12. Primicula? conpressa, B. Pl. 2, figs. 13 and 14. Elliptical, bivalve; valves separated by a plane passing through the longer axis; slightly convex, and with transverse rows of dots.

Hab. St. Augustine.

13. Stauroneis maculata, B. P1. 2, fig. 32. Lanceolate or elliptical, end . slightly produced and rounded; surface punctato-striate, with a large smooth central space.

Resembles S. punctata of Kützing's Bacillarien, Pl. 2l, fig. 9, but is larger, and has the ends not so much produced.

Hab. Enterprise, Florida, where it is common in Iake Monroe, and in serral of the smaller creeks near Mr. Dural's.

14. Surirela circunsuta, B. Pl. 2, fig. 36 . Outline nearly elliptical, with a scarcely perceptible constriction at the middle. Surface with very minute granulations, and a faint longitudinal line through the middle. Edges with a continuous row of nearly obsolete pinnulax.

Hab. Hudson River, West Point; St. Augustine and Enterprise, Florida.

15. Triceratium alternaxs, B. Small, reticulated, triangular; surfice marked with three lines, which, with the portions cut off from the sides, form a hexagonal figure.

Common everywhere along the Atlantic coast and in estuaries; also abundant in the fossil state, in the Infusorial strata of Virginia, and in the rice fields of Georgia and Carolina.

16. Zygozeros (Dexticella?) Mobrulexsis, B. Pl. 2, figs. 34 and 3.5. Frustules quadrangular, compressed, thin, delicately decussatedly-punctate; lateral processes slender; intermediate ones (two at each end) long and slender. Color vellowish. 
I first detected this species in 1848, in soundings from Mobile Bay, and snbsequently I have found it at Sarannilh, Ga, and St. Augustine, Florida. It is a curious and interesting form, with the slape of a Zygoceros, and the spines of a Denticella.

I N F U S ORIA.

1. Difflugia spiratis, B. Lorica subglobose, mimtely gramulated; upper surface with a spiral suture of two or three turns Pseudopodia long, numerous, constantly changing position.

Very common throughout the United States. M. Le Clerc mentions spiral corrugations as occurring on the D. Proteiformis, Elır. His remark, doubtless, alludes to the D. spiralis, which, I think, should be distinguished from the other fornı.

2. Melicerta Nuda, B. Pl. 3, figs. 8, 10 . This is, possibly, only a condition of II. ringens; but no allusion is made, in the worls to which I lave access, to any state of that species in which the granules are not present upon the case. Numerous specimens were seen at Enterprise which were evidently full grown, and which contained eggs, and yet the case was perfectly free from granulations, being clear and transparent as glass. I have referred to such specimens by the name of M. nuda.

3. Peridinium carounianum, B. Pl. 3, figs. 4, 5. Large, processes three; two on one side, and one on the other of the middle groove. Proboscis in the sinus between two processes. Surface coarsely granulate. Color, yellowish brown.

The proboscis moves very rapidly, sometimes in irregular undulations, and sometimes revolving so rapidly as to produce the appearance of a cone, as represented in the fig. of Peridinium fusus, Ehr., given in Pritchard's Infusoria. PI. 4, figs. 2, 23. An appearance of an orifice is obscurely seen on the under side, near the insertion of the proboscis. When mounted in Canada balsam, the shell becomes nearly invisible. The motions of the living animal are very active. I could detect no trace of phosphorescence on agitating in the dark a phial which contained myriads of the living animals.

This fine species occurs in vast quantities among the roots of Lemna in the "Back-waters" of rice fields, Grahanville, S. C. I also found it near Sarannal and in the lakes of Florida, at Enterprise, Pilatka, \&c.

4. Rotifer vestritus, B. Pl. 3, figs. 9 and 14. Body large, elliptical, completely covered by a transparent, jelly-like case, which does not become wrinkled during the motions of the animal.

Hab. Enterprise, Fa. 
5. P'TERODIN mant, B. On Sit. Anastasia Islant, in a small fiesh-water pond, I collected a species of Ptemolina with a carapace nearly twice as large as any specinens of P. patina which I lave ever seen, and diflering somewhat in the undulations of its frontal margin. Although it lias not yet becul sufficiently studied to be accurately described, I give its outline in $\mathrm{Pl}$, 3, fig 19, and have referred to it by the name of P. magna.

6. Philodixa paxxosa, B. Pl. 3, figs. 6, 7. Body large, covered with irregular wedge-slaped projections, armanged in several longitudinal and transverse rows.

Hab. Fnterprise, Fa.

A I G $2 \mathrm{E}$.

1. Apolea ambigua, B. Pl. 3, tig. 3. Frond (?) microscupical, thin, flat, much divided in a dichotomous mamer, surface witl imegular longitudinal markings; color, brown.

Merely to aroid circumlocution, I have referred by the above name to this constantly oceuring form. I know nothing of its real nature; and it is almost as probable that it is the compound support of some of the stipitate infusoria, as that it belongs to the vegetable kingdom. I have never seen either spores or infusoria in connection with it. It occurs everywhere in fresh water in Georgia and Florida.

\section{GENERAL RLAARLS.}

1. It will be seen by the preceding pages, that 275 species of Desmidieie, Diatomacese, and Infusoria have been positively determined as occurring in regions where not one of them was previously known by direct observation to exist. Of these species, thirty-one, or abont one-ninth, are believed to be new, and the others are alrealy known to occur in the Northern States, or in Europe.

2. The identity of many of the nothern species of Desmidiea, \&c., with those of Europe, has been known for several years, and we now have evidence that the same is true with regard to the greater number of the forms occuring in Carolina, Georgia, and Florida. We have thus another illustration of the fact, that the microscopical organisms in fresh water are less affected by differences of climate than almost any other portion of the organic world.

3. Almost every locality examined, whether in fresh or salt water, is shown to have been teeming with organic life even in mid-winter.

4. With regard to the degree of reliance to be placed upon my determinations, I may state, that no one could have criticised each observation more rigidly than I have done, and that I was anxious to adnit no species into my lists which I could not be perfectly certain was identical with the European or Northeru form whose name I might attach to it, while I was equally desirous to record all forms which appeared novel, and which presented characters sufliciently narked to enable other observers to recognize them by my description and figures. I 
have, therefore, omitted many forms which I could not determine sitisfietorily. My guides in studying these bodies, while on the journey, were Ralfs' British Desmidiea, a work whose elaborate descriptions and exquisite ligntes enable the student to determine the species with perfect certainty; Kützing's Diatomaceen oder Bacillarien, which contains many figures of the Diatomacea, both by Elırenberg and Kützing; and "Pritchard's History of Infusoria, Recent and Fossil," which contains abridged descriptions and reduced figures, taken from Ehrenberg's great work, "Die Infiusionsthierchen."

5. The existence of vast quantities of infusorial remains in the carth of the rice fieids in the Southern States is, perhaps, connected with their wonderful fertility. The fact that the species found are chiefly marine, and such as now abound in the salt marshes of the coast, indicates the former presence of salt water much farther up the rivers than it now extends.

6. Although the species found in the rice fields are such as are still living in estuaries or along the coast, those excavated in digging the deep canals of the rice fields, and the ditches of the forts near Savanmah, must have been deposited many hundreds, if not thousands of years ago, and they are, therefore, fully entitled to the name of fossils, and should, I think, be referred to the Post Pleiocene epoch.

7. The vast salt marsh formations of the coast of South Carolina, Georgia, and Florida abound in silicious Diatomacer, whose shells are daily becoming imbedded in mud; so that we have here, in the process of formation, deposits similar in character to the infusorial strata of Virginia and Maryland, and quite as extensive, although usually rather more sandy in their character.

8. It will be seen by table $\mathbf{B}$, that certain species of Diatonacex which occur in the ocean itself, may also live at great distances from the ocean, in estuaries and rivers far above where the surface water is fresh; yet these sime species have never been found in lakes or pools of fresh water, not having a direct 'onmunication, however remote, with the sea. Among the species of this character are Amphiprora pulchra, B., Amphiprora constricta, Ehr., Amphora libyca, Ehr., Bacillaria paradoxa, Ehr., Ceratoneis closterium, Ehr., Ceratoneis fasciola, Ehr., Coscinodiscus subtilis, Ehr., Cerataulus turgidus, Ehr., Navieula elongata, Odontella polymorpha, Kg., and 'Terpsinoë musica, Ehr.

9. The beautiful Terpsinoë musica, Ehr., is an interesting addlition to our native species of Diatomacex. It was first received by Ehrenberg from Mexico, and he has recently proved its existence in the rivers of Texas, (see Monatsbericht der Preuss. Akad. zu Berlin, Feb., 1849 , p. 88 ;) but it was not known to exist in the older States until, by the observations recorded in this memoir, I determined its existence in all our Southern rivers. I lave also specimens of it from Janaica, West hndies, and portions of a closely allied, if not identionl form, from Mindanao, in the Phillipine Lsands. 
10. The observations above recorded will serve to slow how abundant a store of organic beings await the researches of naturalists in the Southern States,forms which, independent of their being among the most delicate and beautiful of all the displays of creative power, are also of the greatest interest, from the important relations which Ehrenberg has proved to exist between them and wide-spread cosmical phenomena.

11. The waters in which $I$ detected the species above recorded, also abounded in many other forms of microscopic life; as, Entomostraca, Tardigradi, Anguilluli, \&c., \&c. Of these I have made no record, as I did not possess sufficient knowledge concerning them. They will well reward the attention of Southern naturalists. 


\section{A P P E N D I X.}

MICROSCOPICAL FORMS FOUND NEAR SALEH, MASS., BY T. COLE, ESq.

For the following interesting list of microscopical forms found near Salem, Mass., I am indebted to Tном Cole, Esq., of that place, who has for several years examined these forms with great zeal, and who, I believe, was the first person to make a systematic study of the American soft skinned Infusoria. This list will be useful for the purpose of comparing the forms of the Northern and Southern States. Thie names employed by Mr. Cole are those used by Ehrenberg, in his large work Die Infusionsthierchen, with the descriptions and figures of which each form was compared.

Volvox sphærosira. "Globator.

Pandorina Morum.

Synura Uvella.

Closterium striolatum.

“ lineatum.

“ turgidum.

" setaceum.

"Trabecula.

“ Lunula.

Amblyophis viridis.

Docidium nodosum.

“ nodulosum.

Euglena acus.

" longicauda.

“ Pyrum.

“ pleuronectes.

“ triquetra.

“ spirogyra.

" Deses.

Chlorogonium euchlorum.

Distigma Proteus.

Dinobryon Sertularia.

Amoeba princeps.

“ radiosa.

Diftlugia proteiformis.

Arcella vulgaris.

Naunema simplex.
Desmidium Swartzii.

“ quadrangulatum.

Staurastrum dilatum.

Xanthidium ramosum.

" aculeatum.

" hirsutum.

" fasciculatum.

Arthrodesmus convergens.

" quadricaudatus.

Odontella Desmidium.

" filiformis.

* Micrasterias heptactis.

. hexactis.

“ Boryana.

. $\quad$ tricyclia.

*Euastrum rota.

“ Crux Melitensis.

“ verrucosum.

“ Pecten.

“ margaritiferum.

Gallionella moniliformis.

Navicula striatula.

“ viridis.

" sigmoidea.

“ splendida.

. Baltica.

“ diagonalis, $(=\mathrm{N}$. angulata ?) 
Eunstia tetraodon.

. pentodon.

" serra.

Synedra ulna.

¿.. capitata.

، lunaris.

Podosphenia gracilis.

Gomphonema acuminatum.

Cyclidium glaucoma.

Peridinium fuscum.

Glenodinium apiculatum.

Stentor Mulleri.

Vorticella ncbulifera.

“ Campanula.

“ Convallaria.

Carchesium polypinum.

Epistylis Galea.

" anastatica.

Cothumia imberbis.

Aetinophrys Sol.

"viridis.

Lacrymaria Proteus.

Coleps hir'tus.

Spirostomum ambigruum.

Chilodon Cuculus ?

Trachelocerca Olor.

Amphileptas Anser.
Ampliileptas monilifer.

" margarititer.

" fasciolus?

Paramecium aurchia.

Croleptus Filum.

“ Piscis.

Oxytricha caudata.

Urostyla grandis.

Stylonychia nytilus.

'Trachelius Orum. " trichophorus.

Oxytricha caudata.

Chetonotus maximus.

$$
\text { " Larus. }
$$

Floscularia proboscidea.

$$
\text { " ornata. }
$$

Notommata longiseta.

$$
\text { " copeus. }
$$

Scaridium longicandum.

Lepadella emarginata.

Dinocharis pocillum.

Stephanops lamellaris.

Rotifer vulgaris.

Philodina aculeata.

Urocentrum Turbo.

Euplotes Charon.

“ patella.

I lave not thought it necessary to cliange any of the above names to correspond with those which I lave adopted. It is necessary, however, to mention that the genus Micrasterias of Ehrenberg is Pediastrum of Meyen, Ralfs, \&c., and of my lists, while the Euastrum of Ehrenberg is in part equivalent to the Micrasterias of Agardh, Ralfs, \&c., whose names I have used.

J. W. B.

Since this Memoir was in type I lave received from Dr. W. C. Danielu, of Savannal, Ga., several specimens of soil from his rice fields, ten miles above Savannalı. These prove to be exceedingly rich in the same species of marine silicious Diatomaces which occur in the soil of the plantations opposite Savannah. One of Dr. Daniell's specimens appears to be almost entirely made up of perfect shells of Coscinodiscus subtilis, Elır. 


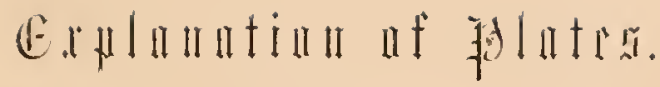

TuE figures on these Plates are little morc thin nucmorandum sketches, few or none of the details of relief, sculpturing, striation, de., being given. They are, however, accurate as far as they go, being all, except wherc otherwise stated, drawn by means of the camcra-lucida, from living specimens. They may serve, therefore, to identify the forms referred to in the descriptions.

\section{PLA T E I.}

FIG. I. Cosmarium depressum, 13 .

2. Docidium undulatum, B.

3. " minutum, Ralfs.

4. " nodosum, B.

5. Micrasterias quadrata, $\mathrm{B}$.

6. " arcuata, B.

7. “ expausa, B.

8. Docidium hirsutum, B.

9. Triploceras verticillatum, B.

10. “ gracile, B.

11. Nicrasterias ringens.

12. " pimnatifida, $\mathrm{Kg}$.

13. " incisa, Kg.

14. Sphærozosma serratum, B.
Fı. 15. Didymocladon cerbcrus, B., side view. 16. " cerberus, B., end riew. 17. " " longispinum, B.

18. Staurastrum enorme, Ralfs.

19. Nicrasterias oscitans, Ralfs, with abnormal teeth at $a$ and $l$.

20. Nlicrasterias denticulata, Ralfs. It has broad and slightly hirsute ends, which I have not seen mentioncd as occurring in the British specimens.

21. Scale for all the figures in this Plate, being $\frac{5}{300}$ ths of au inch, magnified equally with the sketches.

\section{PLA T E II.}

Fıg. 1. Aclinanthes longipes? Ag. Charleston.

2. Amphiprora quadrifasciata, B. Tampa.

3. " " " seen obliquely.

4. " " " side riew.

5. " constricta, Ehr. 'Tampa.

6. " " side vicw. Tampa.

7. " " Ehr, large specimeu. 'l'ampa.

8, 9. Amphiprora alata, Ehr. St. Augustine.

10 . men, seen edgewise.

" " a coutorted speci-

11. Achnanthes, a single frustule, species undetermined. Volusia.

12. Amphora libyca, Ehr.

13. Pyxidicula compressa, B. St. Augustine.

14. " " " cross section of one valvc.

15. Amphiprora ornata, B. Withlacoochce R.

23. " " " a contorted specimen.

16. “ pulchra, D., side view.

18. " " " larger specimen,

font view. Fnterprice.
FIG. 17. Ceratoneis closterium, Ehr. St. Augustine.

19. Achnanthes? arenicoli, B. Tampa.

20. Amphora amphioxys, B., rentral surface. St. Augustine.

21. " " oblique view.

22. " " " side view.

24, 25. Campylodiscus argus, B. Hudson River.

26. Cerataulus turgidus, Ehr. Hudson River, horns absent.

27. Cerataulus turgidus, Ehr., with the horns.

28, 38. Pinnularia permagna, B. Hudson Iiver.

29. Navicula cuspidata? Ehr. Pilatka.

30. Diatoma Ehrenbergii, Kig. Pilatka.

32. Stauroneis maculata, B. Enterprise.

33. Pinnularia Coupcrii, B.

34, 35. Zygoceros (Denticella ?) mobilensis, B.

36. Surirella circumsuta, B.

37. Scale for all the figures on this Plate, being $\frac{5}{1000}$ ths of an inch, magnified equally with the drawings. 


\section{PLA T E III.}

F1G. 1. Biforine, from Pistia stratiotes, discharging F1a.9, 14. Rutifer restituz, B. Enterprise. See its raphides.

2. Conochilus volvox, Ehr., without the casc. Enterprise.

3. A porea ambigua, B. Sec p. 42.

4, 5. Peridinium carolinianum, B. Grahamville, S. Ca.

6, 7. Philodina pamosa, B. No. 6 , by the camera; No. 7, by the eye.

8, 10. Melicerta nuda, B. See p. 41. Enterprise.

11. Cothurnia maritima, Ehr. Tampa.

12. Notommata longiseta, Ehr. Entcrprisc.

13. Portion of arm of Stephanoceros Eichhornii? from Enterprise; showing latcral, not rerticillate eilia. In other respects the Ameriean specimens agrec with Ehrenberg's figures. p. 41, fig. 9, extended, and drawn by the cye: fig. 14 , contracted, and drawn by the camera lucida.

15. Cothurnia maritima? Ehr. Tampa.

16. Acincta Lyngbyii? E'rr. St. Augustine.

17. Brachionus urceolaris, Ehr. St. Argustine.

18. Cothurnia havniensis, Ehi. Tampa.

19. Pterudina magna, l3. Anastasia lsland, Fa. This is drawn to the seale of fig. 25.

20, 21. Brachionus polyacanthus, Ehr. Enterprise, Fa.

22. Acincta mystacina. Pilatka.

23. Cothụınia imberbis, Ehr. Pilatka.

24. Scale A, for figs. $1,3,4,5,11,12,17$, and 21 , being $\frac{5}{1000}$ ths of an inch, magnified equally with these figures.

25. Scale $B$, for figs. $2,6,7,8,9,10,14,15$, 16,19 , and 23 , being $\frac{5}{10}$ the of an inch, magnified equally with the drawings. 


\section{Plate 1.}

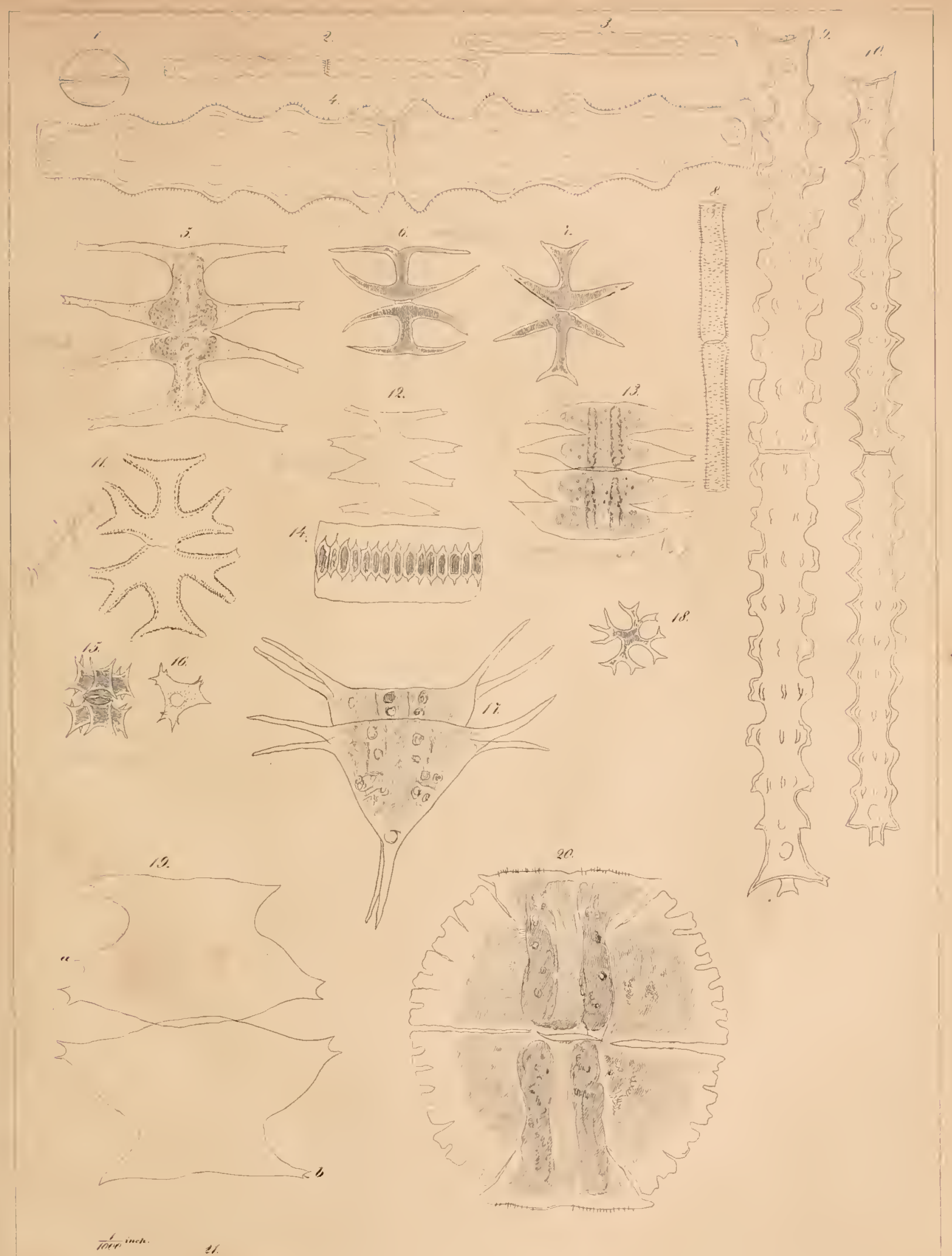



Plate 2 .

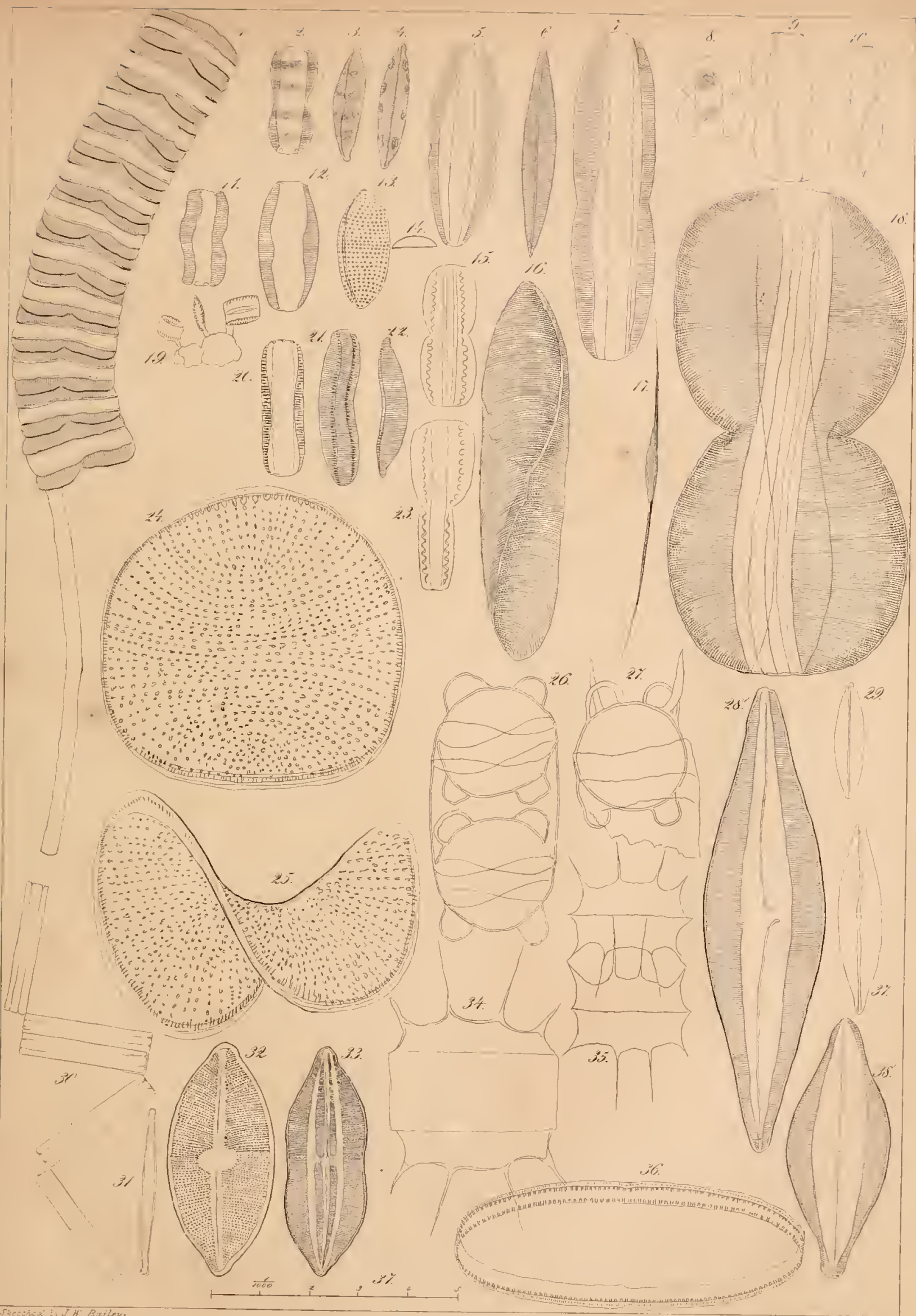



Plate 3.

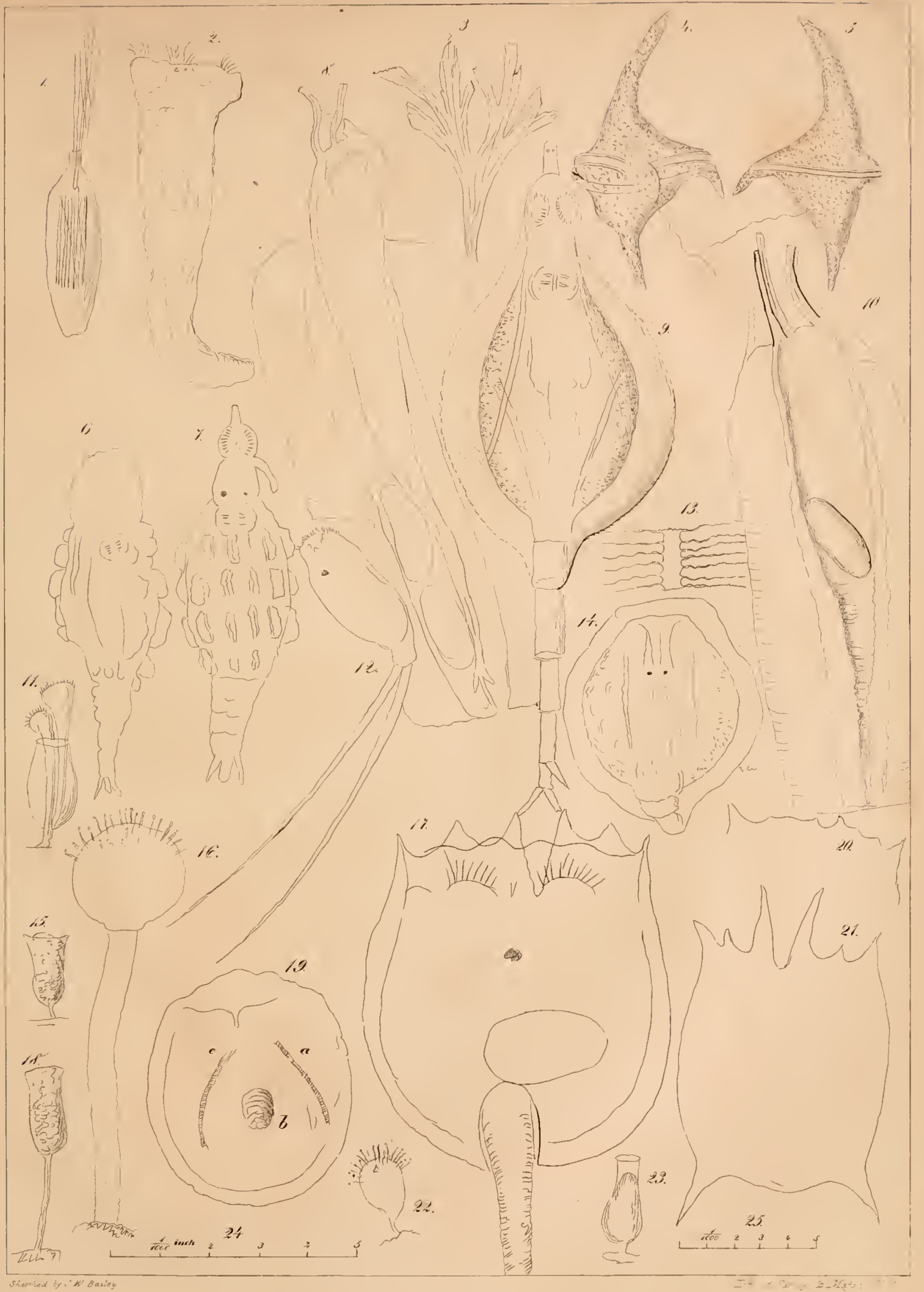

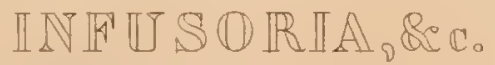



- 
chestose

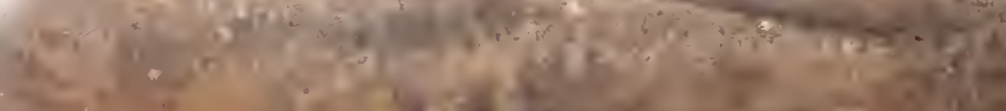

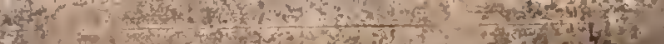

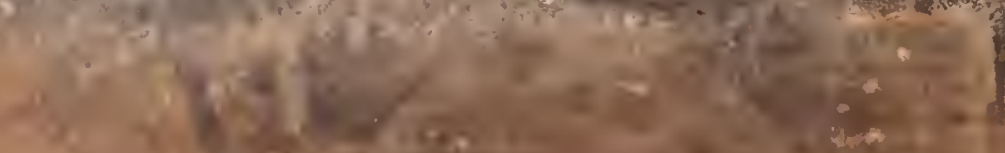

$+0$

$+2$

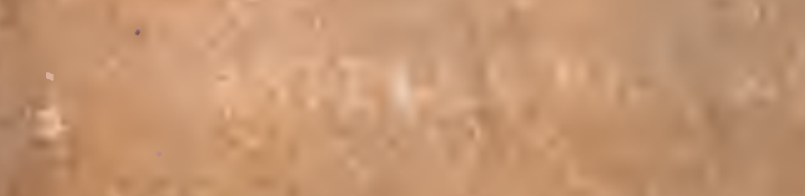

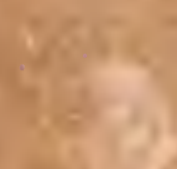

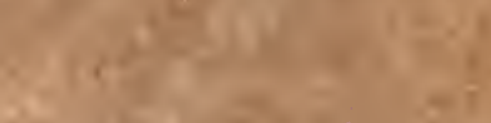
or

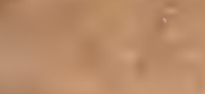

\section{$5 \times x^{2}$}

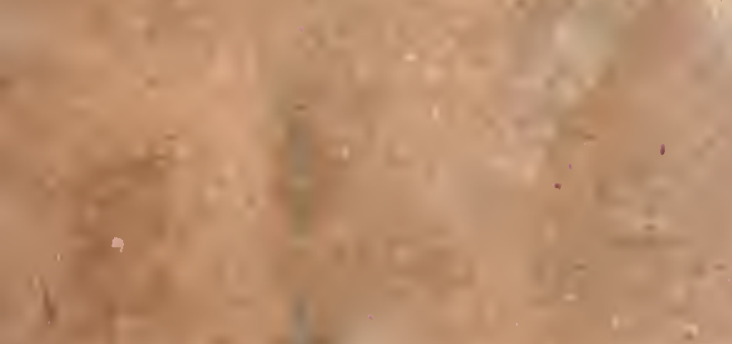

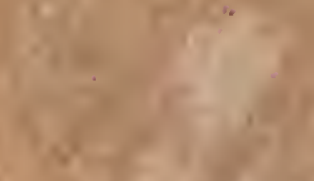

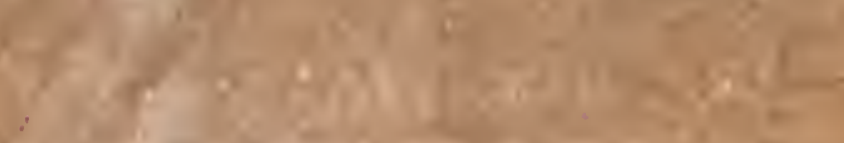
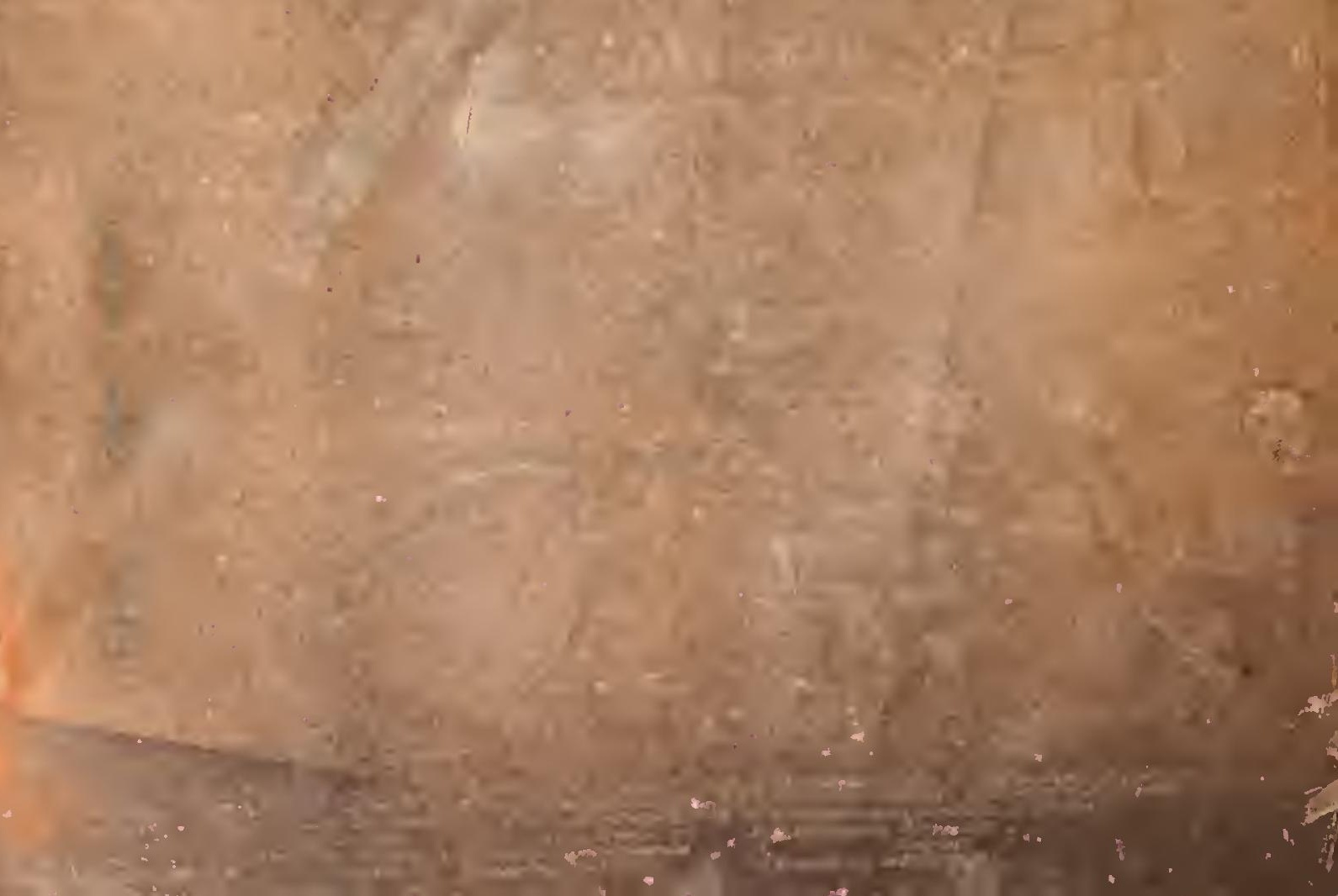



